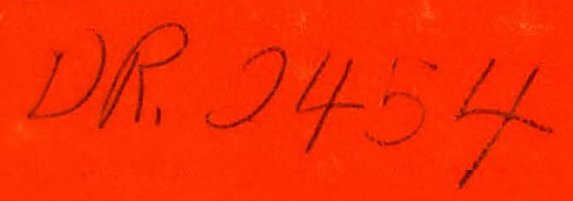

February 1979

\title{
Organized Labor and Solar Energy
}

Market Development Branch

Technology Commercialization Division
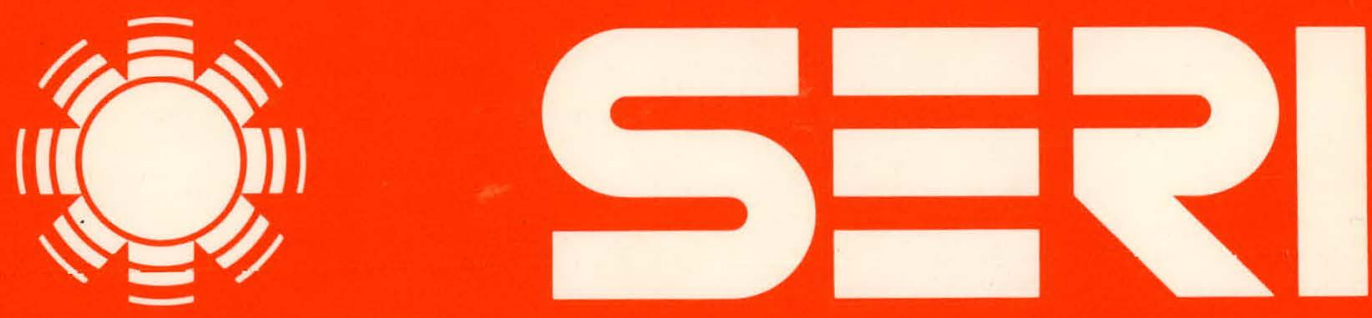

Solar Energy Research Institute

A Division of Midwest Research Institute

1536 Cole Boulevard

Golden, Colorado 80401

Operated for the

U.S. Department of Energy under Contract No. EG-77-C-01-4042

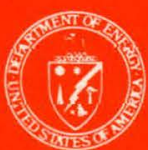




\section{DISCLAIMER}

This report was prepared as an account of work sponsored by an agency of the United States Government. Neither the United States Government nor any agency Thereof, nor any of their employees, makes any warranty, express or implied, or assumes any legal liability or responsibility for the accuracy, completeness, or usefulness of any information, apparatus, product, or process disclosed, or represents that its use would not infringe privately owned rights. Reference herein to any specific commercial product, process, or service by trade name, trademark, manufacturer, or otherwise does not necessarily constitute or imply its endorsement, recommendation, or favoring by the United States Government or any agency thereof. The views and opinions of authors expressed herein do not necessarily state or reflect those of the United States Government or any agency thereof. 


\section{DISCLAIMER}

Portions of this document may be illegible in electronic image products. Images are produced from the best available original document. 


\author{
Printed in the United States of America \\ Available from: \\ National Technical Information Service. \\ U.S. Department of Commerce \\ 5285 Port Royal Road \\ Springfield, VA 22161 \\ Price: \\ Microfiche $\$ 3.00$ \\ Printed Copy $\$ 5.25$
}

NOTICE

This report was prepared as an account of work sponsored by the United States Government. Neither the United States nor the United States Department of Energy, nor any of their employees, nor any of their contractors, subcontractors, or their employees, makes any warranty, express or implied, or assumes any legal liability or responsibility for the accuracy, completeness or usefulness of any information, apparatus, product or process disclosed, or represents that its use would not infringe privately owned rights. 
SER I /TR-62-148

UC CATEGORY: UC-13

ORGANIZED LABOR AND SOLAR ENERGY

MARKET DEVELOPMENT BRANCH

TECHNOLOGY COMMERCIALIZATION DIVISION

FEBRUARY 1979

This report was prepared as an eccount of work sponsored by the United States Govemment. Neither the IUnited States nui the United States Department of Energy, nor sny of their employes, nor any of their contractors, subcontracins any werranty, express or implied, or asumes, makes liability or responsibility for the accuracy, conpletess or usefulness of any information, anchy, completeness prucess disclosed, or repenation. apparatus, prodlict of process disclosed, inr reprosents Utat lts use would not
infringe privately owned rights.

Solar Energy Research Institute

1536 Cole Boulevard Golden, Colorado 80401

ADivision of Midwest Research Institute

Prepared for the

U.S. Department of Energy

Contract No. EG $\cdot 77 \cdot \mathrm{C} \cdot 01 \cdot 4042$ 


\section{FOREWORD}

Both union and nonunion labor share in the national responsiblity for the development of alternative sources of energy to reduce the nation's dependence on diminishing sources of foreign and domestic fossil fuels. Further, the introduction of solar energy systems offers a new and rapidly growing market for the skills of the manufacturing and construction crafts.

To better understand the needs and concerns of the union community and to establish a foundation for working together in the advancement of solar energy applications, SERI has sought the positive involvement of organized labor and a cooperative working relationship that will enhance the commercial development of solar energy.

To date, SERI has initiated communication at both national and local area levels with appropriate union offices and officials. Through such communication channels, SERI will be in a position to keep union officials abreast of developments in solar energy and simultaneously to learn of the problems that unions may have regarding the progress and changes in solar technologies.

It has been assumed throughout the project that the degree to which solar energy becomes a substantial alternative energy source in the coming years will depend to a considerable extent on its acceptance by a diverse multiplicity of American "publics" or interest groups. This report describes an important first step in gaining organized labor's acceptance of a role for solar energy in labor's future.

This report was prepared by Rob Livingston and Dana Moran of the SERI Technology Commercialization Division and is based upon material submitted by Herrick S. Roth and Ed Porkorney, of Herrick Roth Associates, Inc., prime contractor to SERI for material containfd in this repert.

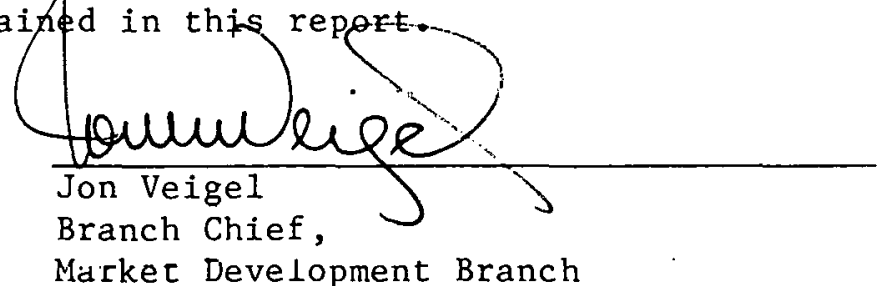

Approved for:

SOLAR ENERGY RESEARCH INSTITUTE

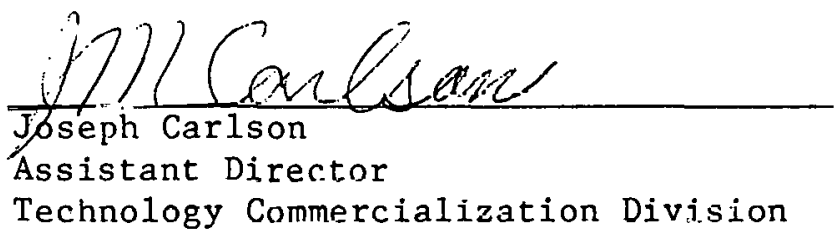


TABLE OF CONTENTS

Page

Foreword....................................... ii

Abstract..................................... 1

1.0 Introductory Summary $\ldots \ldots \ldots \ldots \ldots \ldots \ldots \ldots \ldots \ldots \ldots \ldots \ldots \ldots \ldots \ldots$

2.0 General Evaluation of National Labor Leadership

and Planning for Workshops.......................... 9

3.0 Overview of Union Jurisdtction..................... 11

4.0 Indepth Analysis of Princlpal Solar-Related

Unions....................................... 21

5.0 Unions Included in Interviews and Selected Comments......... 25

5.1 Boilermakers, Iron Ship Builders, Blacksmiths,

Forgers, and Helpers; International Brotherhood

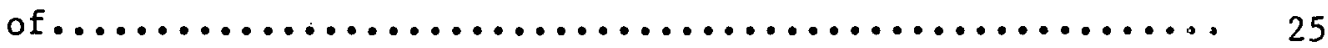

5.2 Bricklayers and Allied Craftsmen, International

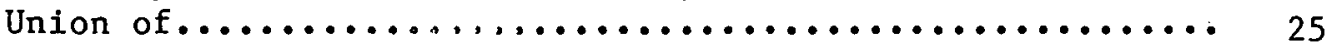

5.3 Carpenters and Joiners of America, United

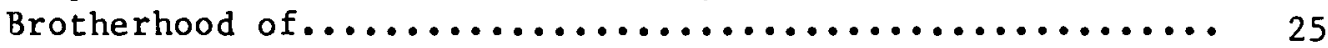

5.4 Electrical, Radio and Machine Workers;

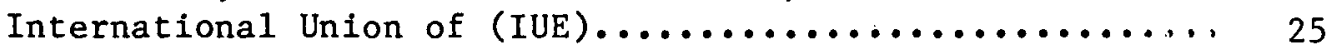

5.5 Electrical Workers, International

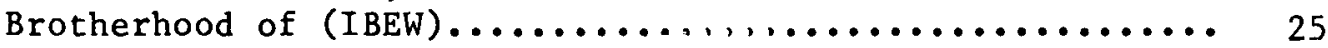

5.6. Heat and Frost Insulators and Asbestos Workers, International Assuclatión of...................... 26

5.7 Laborers' International Union of North America

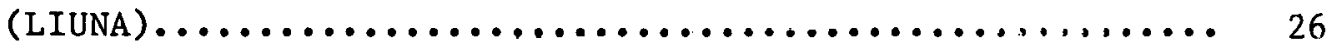

5.8 Machinists and Aerospace Workers, International

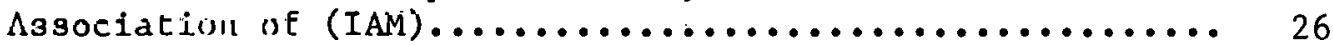

5.9 Operating Engineers, International Union of........... 27

5.10 Operative Plasterers and Cement Masons, International Association of ..................... 27

5.11 Painters and Allied Trades, International

Brotherhood of ................................ 27 
TABLE OF CONTENTS (cont'd)

$\underline{\text { Page }}$

5.12 Plumbing and Pipe Fitting Industry of the United States and Canada, United Association of Journeymen and Apprentices of (UA)......................... 27

5.13 Sheet Metal Workers, International Association

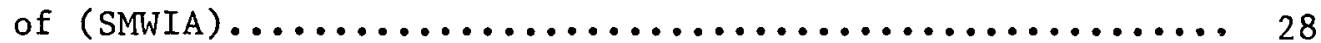

5.14 Steelworkers of America, United (USWA).............. 28

5.15 Teamsters, International Brotherhood of .............. 28

5.16 United Auto workers (UAW)...................... 29

5.17 United Slate, Tile and Composition Roofers, Damp and Watcrproof Workers Association.............. 29

APPENDIX A

National Labor Leadership Workshop Overview............... A-1 APPENDIX B

Labor Leader Contacts........................... B-1 


\section{$\therefore$ ABSTRACT}

This report focuses on the question of how the Solar Energy Research Institute and the Department of Energy can work to increase the role of trade unions as producers, installers, and consumers of solar energy technology. It provides an overview and understanding of the skills and jurisdictions of organized labor and how this community might best prepare itself for the transition to working with and using solar technologies. It further discusses the new growing market for the skills of the manufacturing and construction crafts as well as the areas in which specific unions might have the greatest impact on the commercialization of solar technologies. The. report includes a summary of the National Labor Leadership Workshop on Solar Technology (June 1978) and provides a basis for continued communication with this most important and influential part of the working and consuming public. 
THIS PAGE IPTTANTIONULLY LEFT RI ANK 


\section{SECTION 1.0}

\section{INTRODUCTORY SUMMARY}

This report describes a labor community ready to move in the area of alternative energy sources. That communlty is cooperative, willing to learn, and ready to accept informed assistance from SERI. To provide personal contact on an informal basis between labor leaders and SERI representatives, a National Labor Leadership Workshop was sponsored by SERI and hosted by Robert Georgine, President of the AFL-CIO Building and Construction Trades Department on June 9, 1978, at the George F. Meany Labor Studies Center in Washington, D.C. This provided an excellent forum for labor leaders representing 13 International Unions to meet with officials of SERI and the U.S. Department of Energy (DOE) to discuss the role and implications of organized labor's involvement in the developing of solar technologies and how SERI and the Regional Solar Energy offices can best address itself to working with trade unions as producers, installers and consumers of solar technology. (The detailed overview of the workshop can be found in Appendix A.) During the course of this project SERI sought to develop channels of communication with the national unions by:

- identifying and communicating with key national and state union officials;

- conducting a national workshop that included high-level participants from the Department of Energy (DOE), SERI, and labor;

- identifying (through surveys and research) the labor programs, policies, organizational structure, and other matters of concern of which energy officials ought to be cognizant;

- conducting in-depth intervicwo with unlon leaders to determine the relationship of the given union to solar technology as well as the degree to which the union might: have a stake in a solar energy future;

- organizing prototype regional conferences aimed at bringing regional solar energy centers together with regional or state representatives of area building and construction trade councils;

- laying out a strategy by which SERI could continue to foster effective relations with the labor community making that comminity a working part.ner in SERI's fuLure efforts; and

- developing a comprehensive report of the work of the project as well as a compendium of labor leaders contacted so that SERI and DOE can continue to huild on the base begun by the project.

In his remarks to the participants at the National Labor Workshop, Paul Rappaport, Director of SERI, indicated his pleasure at the direct contact with the unions which the workshop afforded. He empliasized that SERI is a catalyst, not a policy setter. The industry, unions, and other interested 
parties should formulate and set standards. To the extent that SERI is a catalyst, the workshop will be a step toward looking into the future.

At the conclusion of the conference Dr. Rappaport summed up the conference proceedings by indicating that many excellent ideas and suggestions had surfaced during the course of the workshop. These included:

- that colar energy products and solar energy installations should be kept as simple as possible, and should be prescntod slearly and succinctly;

- that solar energy installation and service should be done by skilled craftspeople to increase reliability;

- that good standards should be promulgated by the industry with input from labor iallier than dictated by the government;

- that the government should give consideration to providing some funding for the solarizing of labor training facillties;

- that any jurisdictional disputes between or among the vartuus tradcc will be worked out;

- that the matter of training is important, and that SERI will provide information, concepts, course materiale, and other material that unions consider helpful to their training programs; and

- that SFRI should continue open and cand1d discussione with organized labor including fostering communicatlums between trade unions and the Regional Solar Energy Centers which have been established.

Several of the key labor points of view and recommendations that appeared to have some shared basis among the participants at the June 9 workshop can be summarized as follows. These views appear in greater detail later in the text covering the proceedings of the National Labor Workshop.

- Labor appreciates the early attencton being paid by SERI to its potential role 1n solar energy, and looks forward to further cooperative relations with SERI;

- Labor is interested in being kepr appriscd of develnpments in solar energy and may be willing lu use ito communiration links to its rankand-file members to disseminnte information about solar alternatives;

- Labor believes that governmental efforts in the training field are ignoring the fact that labor-tralned craftspeople already posses the basic skills required for the solar technology field, and that any additional training needed is a relatively minor increment;

- Labor is concerned that the essential simplicity of solar energy is not reflected in instruction manuals, standards, and specifications, with the result that consumers may be frightened off by what they view as a complex and mysterious product; 
- Labor does not appear unduly concerned about actual or potential jurisdictional problems among unions as such problems might impact upon their work in solar energy;

- Labor welcomes information from SERI on solar energy but it also wants input into SERI's future (e.g., as in the case of a representative from labor on SERI's advisory groups); and

- Labor is willing to help develop a viable solar industry.

Labor's recommendations to DOE and SERI at the National Labor Workshop consisted principally of the following:

- the establishnent of a labor representative or labor advisory committee to SERI and or DOE on policy issues that may effect the labor community;

- close and continuing ties with the Regional Solar Energy Centers;

- publications from DOE, SERI, and the Regional Solar Energy Centers to labor discussing issues of interest to the labor community;

- provision of input as requested to the National Labor Unions at their National Conventions held each year; and

- development and maintenance by SERI, DOE and labor of close and continuing ties with the Citizen/Labor Energy Coalition.

One of the principal findings during the course of this project is that while actual labor experience has been rather limited and generally confined to a few key unions, interest among virtually all the trades that might potentially benefit is extremely high. There is general awareness and a concern that America's depondence on fossil fuels will be reduced and that other energy sources must begin to assume a larger role. Union leadership appears aware that one such source is solar technology; this new technology poses the possible promise of the creation of jobs as well as a partial solution to the energy crisis.

The project staff met personally with one or more national leaders of 18 international unions as part of this project. The purpose of these initial personal meetings was to apprise the labor leaders of SERI's operations and objectives and to probe the interest and understanding of Labor's leadership as it related to solar energy relative to solar energy.

In addition, return visits and interviews were conducted following the completion of the leadersh1p workshop which were aimed at examining the structure of the union as well as the union's interest in and relationship to a possible solar energy future. Field visits were made with the chief officers of 22 building and construction trades councils in 18 states. These onsite discussions with regional labor leaders provided SERI an opportunity to extend its contacts to the grassroots level while also permitting SERI to examine significant differences between the national, state, and local leadership. 
Below is a listing of the unions with which discussions have been held as well as a listing of the states and numbers of building and construction trades councils (BCTC's) visited. In addition, Appendix B provides the titles and addresses of their key personnel.

Table 1-1. INTERNATIONAL UNIONS CONTACTED

Boilermakers

Carpenters

Cement Masons

IBEW (Electrical Workers)

Insulators

Iron Workers

Laborers

Machinists

Oil, Chemical \& Atomic Workers
Operating Engineers

Painters \& Glazers

Plumbers \& Fitters (UA)

Roofers

Sheet Metal Workers

Steelworkers

Teamsters

UAW (Auto Workers)

Wood, Wire \& Metal Lathers

Table 1-2. STATES/NUMBERS OF BUILDING AND CONSTRUCTION TRADE COUNCILS VISITED

Arizona (2)

Callfuitila (1)

Culorado (1)

Connecticut (1)

Delaware (1)

Florida (1)

Georgia (1)

Maine (1)

Maccachusetts (1)
Michigan (1)

Minnesota (2)

New Jersey (1)

New York (1)

Oregon (1)

Pennsylvania (1)

Khode Island (1)

Texas (2)

Washington (2)

In general, the process developed to date las hean $A$ ouccessful one and projert efforts are beginning to bear fruit. As an example, one need only look at the in-depth analysis of the Sheet Metal Wuikers Intcrnational Assoriation (SMWIA). Further evidence of this on the part of Sheet Metal Workers is revealed in a speech by Edward Carlough, Presldeul of the union, to the Solar Energy Industrles Association (SEIA) on netoher 1, 1978. Tn that speech $\mathrm{Mr}$. Carlough made a significant commitment on behalf of his union to solar technology--and to the integrity of workmanship in this union. The Sheet Metal Workers are guaranteeing the workmanship of any solar installation performed by their union members. The applicable portion of Mr. Carlough's speech appears below: 
The Sheet Metal Workers International Assocation will guarantee the workmanship of any solar installation in any residence--either new work or retrofitted work--that is performed by union workers employed under a collective bargaining agreement with a sheet metal and air conditioning contractor.

If any residential solar customer feels that their installation has received unsatisfactory, inferior, or shoddy workmanship, he may call our international union, and we will send a trained official to inspect the job and have the problem areas corrected. If this work is necessary, it will be done free of any charge to the customer. A customer need only call the Solar Energy Department of the Sheet Metal Workers, and we will assign a person to inspect that job and seek to correct it. The telephone number in Washington is (202) 296-5880.

I know of no such guarantee by any other organization or company in the solar field. It is Sheet Metal's way of underwriting our belief that the only way to get a good solar heating job is do that job with union people. In that way we can drive out the flyby-night artists from the solar heating and cooling industry; we can reassure the public that they are getting the best possible work; and we can increase consumer receptivity to the challenge of installing solar air systems for heating and cooling.

We are committed to solar. Sheet Metal Workers believe it has a great future. Even more important, we believe it has a great present, and we should be doing more solar work not only in the utopian years ahead--as some contractors suggest--but today. Solar is now. And the best solar is union solar.*

The focus of SERI's efforts thus far has been communication. The conference recommendations stressed heavily how vital are communication ties between SERI - and the labor community, and how these channels of communication may be better built, maintained, and strengthened. Whatever the format, continued communcation with the union community is essential: Not only wlll that community play a significant role in the production, distribution, installation, and maintenance of solar technology, but the community represents over 20 million Americans who have become a prime target for consumer utilization of solar products.

\footnotetext{
*Mr. Edward J. Carlnugh, General President, Sheet Meeāl Workers, National Labor Leadership Workshop on Solar Technologies, June 9, 1978, George F. Meany Labor Studies Center, Washington, D.C.
} 
THIS PAGE INTENTIONALLY LEFT BLANK

8 


\section{SECTION 2.0 \\ GENERAL EVALUATION OF NATIONAL LABOR LEADERSHIP AND PLANNING FOR WORKSHOPS}

Judging from comments received from labor leaders both at the June 9 "Workshop on Solar Technology" and from information gained through followup telephone conversations with select participants, the workshop succeeded in accomplishing its principal purpose: to bring labor leaders, SERI, and DOE together in an informal effort to lay a communication basis for future cooperation in the solar energy field.

Feedback from labor leadership has been particularly positive among those unions which have been most deeply involved in--or are actively seeking to become deeply involved in--solar energy. They include the Sheet Metal Workers, the Plumbers and Pipe Fitters, the Carpenters, and the IBEW; equally positive reaction was received from the Laborers and the United Auto Workers (UAW).

Labor participants contacted about their evaluation of the workshop pointed to four elements that they considered highly positive:

- The workshop was initiated by a quasi-governmental entity on its own initiative rather than being forced on initiators by outside pressure;

- The workshop was open and informal and permitted free exchange rather than the tendency toward conferences where the guest speaker "speaks at" the rest of the participants;

- The workshop brought various building trades together in a positive spirit and atmosphere; and

- The workshop left participants with a positive image of SERI thus enhancing the interest in solar technology among labor participants.

An indication of the positive feeling of participants toward the workshop was demonstrated in the following in-depth interviews with labor leaders. The positive response among labor leaders to holding such meetings implies a willingness for further cooperation with SERI.

Following the national Labor Leadership Workshop at the George Meany Center in June 1978, SERI proceeded to work with the Regional Centers in sponsorship of prototype workshops and seminars in reglonal settings. Such workshops bring representatives of Regional Solar Energy Centers together with local, state, and regional labor leaders. Representatives of the international untons also participate where the skill areas of a given top-level union official are appropriate to the substance of the workshop. 
The first such workshop was sponsored principally by the Northeast Solar Energy Center which comprises ten states in the New England and Middle Atlantic area. The initial workshop involved the six New England states in the region, while a later workshop included the Middle Atlantic states. In addition, a workshop for the 12 North Central states falling within the midAmerican solar energy complex took place in late 1978.

Regional Solar Energy Centers will serve as host of regional workshops. Invitations to all workshops (for the states involved) will go to each of the international unions most associated with the production, installation and distribution of solar technology; to the chief executive office of each AFLCIO state central body; and to the chief officers of related building and construction trade coulicils.

In the several dozen onsite visits. to state central bodies and to related building and construction trades counc1ls, there existed almost uniform agreement among union representatives that attempts be made to draw communication lines between local unions and solar energy representatives. The Regional Solar Energy Centers are moving to provide these communication lines. 


\section{SECTION 3.0 \\ OVERVIEW OF UNION JURISDICTIONS}

The tables which appear later in this section describe the various international unions either involved with, or potentially involved in, solar technology. The tables include the skills the union represents, and the solar technology to which that union might relate.

Solar Energy Research Institute personnel visited the labor leaders to determine their activities and attitudes in two major areas:

- actual and potential jurisdictional disputes between and among unions in the area of solar construction and installation; and

- labor training programs, plans, and needs as they relate to. solar technology.

With respect to the first area--that of jurisdictional disputes--SERI ascertained that only minor disputes have occurred to date. The Sheet Metal Workers and the Plumbers and Fitters (the two principal unions involved with solar energy thus far) have a provisional international agreement for respective cooperation in the field of solar installation. So far, the agreement has operated successfully to maintain harmony between the two unions' efforts in solar energy.

The absence of jurisdictional disputes at present may be more a function of the fact that few unions have yet to get deeply involved in solar energy. It could well be that some painful jurisdictional disputes may occur as solar technology is developed, commercialized, and expanded across the various solar energy alternatives.

Concerning possible jurisdictional difficulties, the early communications established with the unions place SERI in a position to spot such potential problems before they become a major obstacle to snlar onergy developuinl. GERI cannot and should not seek to solve jurisdictional disputes among unions; discussions with labor leaders have already drawn the attention of the unions to such potential disputes in the solar energy field. Unlike the normal pattern in their relationship with new technologies, the various unions have had the opportunity to address the jurisdictional question before labor has produced and installed the new technology.

Only the Sheet Metal Workers have established sophisticated training programs for apprentices and journeymen which specifically focus on the additional skills required for solar installation. Yet at the national workshop, the various other unions involved with solar energy expressed interest in incorporating a solar technology training feature. Since labor unions believe that present solar technology draws principally upon skills which trained union workers already possess, and since only minor additional training is needed, none of the unions--the Plumbers and Fitters, Carpenters, Taborers, IBEW--crpressed any concern about the capability of their union to incorporate appropriate training mechanisms for solar energy. 
The accompanying tables display the general jurisdiction and the skill areas of the various unions.

Over 100 selected building and construction trade councils across the nation were surveyed to provide some indication of the extent to which solar activity has taken place under the aegis of building and construction trades. Responses from the survey were combined with onsite visits to 18 states and 22 councils to produce a composlte susvey of activity lovels nn snlar technology among the country's building and construction trade councils.

The survey of the building trades councils provides empirical evidence for what one might intuitively expect would be the case: that solar development is only beginning to attect the energy landscapc, and that 1ahnr--both organized and unorganlzed--must address the noeds of the new energy force in the nnt-too-distant future.

The results of the survey of the building and construction trades councils are displayed as follows: 
Table 3-1. OVERVIEW JF UNION JURISDICTIONS SKILI.S, SIZE, AND LEGAL COVERAGE

\begin{tabular}{|c|c|c|c|c|}
\hline UnION & $\begin{array}{l}\text { GENERAL } \\
\text { JURESDICITSON }\end{array}$ & SKTILL. $\Lambda$ REFAS & SLZE & $\begin{array}{l}\text { LEGAL } \\
\text { COUERAGF }\end{array}$ \\
\hline Asbestus Workers & Construction Insuiation & $\begin{array}{l}\text { Building Craft } \\
\text { Insulators (Packaged } \\
\text { and Forced Air) }\end{array}$ & Under $\cdot 50,000$ & NLRA , \\
\hline $\begin{array}{l}\text { Auto Worbers (JAW) } \\
--(\text { Also, Aerospace } \\
\text { and Agricultural } \\
\text { Implement Workers) }\end{array}$ & $\begin{array}{l}\text { Auto, Space and Agricultural } \\
\text { Industrlal and Smell Parts. } \\
\text { Plants }\end{array}$ & $\begin{array}{l}\text { All Ranges of Skflls-- } \\
\text { Machine Operitors and } \\
\text { Mechanics. }\end{array}$ & $1,500,000$ & NLRA \\
\hline $\begin{array}{l}\text { Bollermakers (Also, } \\
\text { Shipbutiders) }\end{array}$ & Construat lon and Manufacturing & $\begin{array}{l}\text { Onsite and Fixed Plant } \\
\text { Forgers and Installers. }\end{array}$ & 170,000 & $\begin{array}{l}\text { NLRA } \\
\text { iNRLA. }\end{array}$ \\
\hline Bricklayers & $\begin{array}{l}\text { Construetion Sité, Generally, } \\
\text { and Pre:ab Factories in a Few } \\
\text { Instances }\end{array}$ & $\begin{array}{l}\text { Brick, Mortar and Stone, and } \\
\text { Composition Block Masons }\end{array}$ & 160,000 & $\begin{array}{l}\text { SLRA } \\
\quad .\end{array}$ \\
\hline $\begin{array}{l}\text { Elecerical Workers, } \\
\text { International } \\
\text { Brotherhocd of } \\
\text { (I Btw) }\end{array}$ & $\begin{array}{l}\text { Construct lon, Factory and } \\
\text { Electrical and Communtcation } \\
\text { Stores and Services }\end{array}$ & $\begin{array}{l}\text { Journeymen Electronics-- } \\
\text { lleavy Construct Lon, Main- } \\
\text { tenance, Dutside and Inside } \\
\text { Wiremen, Manufacturing Line } \\
\text { Range of Skills, and } \\
\text { Transportation Industry }\end{array}$ & 880,000 & $\begin{array}{l}\text { NLRA } \\
\text { NKLA }\end{array}$ \\
\hline Englneers, Operating & $\begin{array}{l}\text { llighway and lleavy Construction; } \\
\text { Bullding Operation (Heating and } \\
\text { Cooling) }\end{array}$ & $\begin{array}{l}\text { Operate and "Site" } \\
\text { Maintain all. Heavy Job Sice } \\
\text { Equipment, Cranes, Fixed } \\
\text { Plant Boilers and AC/Heating }\end{array}$ & 420,000 & NI.RA \\
\hline
\end{tabular}


Table 3-1. (continued)

\begin{tabular}{|c|c|c|c|c|}
\hline UNLUN & $\begin{array}{l}\text { GENEKAT. } \\
\text { UURISISICILION }\end{array}$ & SKIILL AREAS & $S[Z E$ & $\begin{array}{l}\text { L.EGAI } \\
\text { CUVIERAGE }\end{array}$ \\
\hline Elevator Constructoass & $\begin{array}{l}\text { All Vertical, Horlzonsel and } \\
\text { Grade Mriving Lifts }\end{array}$ & $\begin{array}{l}\text { Iastallers, Temporary and } \\
\text { Perinanent Fievators, Statrs, } \\
\text { Walks and Guide Rails andfor } \\
\text { Shafts }\end{array}$ & $35,000+$ & NLRA \\
\hline $\begin{array}{l}\text { Class and Cetainic } \\
\text { Workers (Also, Glass } \\
\text { Workers Union, } \\
\text { Anerican Flint) }\end{array}$ & 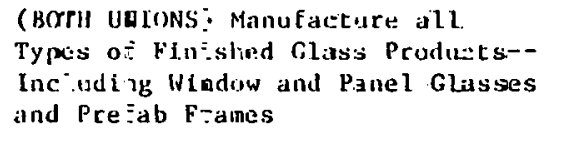 & $\begin{array}{l}\text { Range of Assembly Line Skills } \\
\text { from Helpers to Skilled } \\
\text { Mechantes }\end{array}$ & $\begin{array}{l}\text { Fach berween } \\
20,000 \text { \& } 25,000\end{array}$ & NLRA \\
\hline Iron Workers & Bridge and $S$ :ructural Iron Wark & $\begin{array}{l}\text { Skilled Totally--At Least } \\
\text { Journeymen on any Job Site }\end{array}$ & 100,000 & NLRA \\
\hline Lahocers & $\begin{array}{l}\text { Comstriaction Craft Helpers; Erefab } \\
\text { Cenent, Composteton Block, ard } \\
\text { Sheet hall } 1 \text { Manufactu:fing }\end{array}$ & $\begin{array}{l}\text { Basic Helpers; Some Skillid } \\
\text { MachIne Operators }\end{array}$ & 750,000 & $\begin{array}{l}\text { NLRA } \\
\text { NRLAA }\end{array}$ \\
\hline Painters & $\begin{array}{l}\text { Construct for and Equipment } \\
\text { Painting; Di ywall Installation }\end{array}$ & $\begin{array}{l}\text { Palnters, Spray and Brusl:; } \\
\text { Drywall Installers }\end{array}$ & 183,181 & NLRA \\
\hline Pattern Makers. & $\begin{array}{l}\text { Design Meta , Glass and Plastic } \\
\text { Patterns and Molds }\end{array}$ & $\begin{array}{l}\text { Highly Skilled Prefab anc } \\
\text { Plant - Heavy Equipment lnan } \\
\text { and Steel Designs }\end{array}$ & 5,000 to 10,000 & $\begin{array}{l}\text { NLRA } \\
\text { NRI.A }\end{array}$ \\
\hline $\begin{array}{l}\text { Plasterers and } \\
\text { Cement Masons }\end{array}$ & 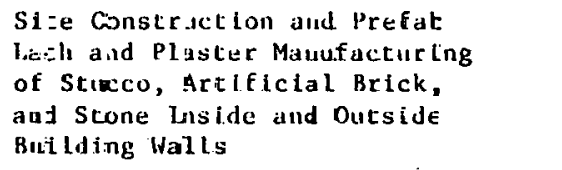 & $\begin{array}{l}\text { Skilled Foundation and Froor } \\
\text { Layers; Plant Manufacturers } \\
\text { and Designers of Brick/s=ucco/ } \\
\text { Plaster glocks and Walls }\end{array}$ & 65,000 & NLRA \\
\hline $\begin{array}{l}\text { Plumbers and Eipe- } \\
\text { fitters, United } \\
\text { Assuc. (UA). }\end{array}$ & $\begin{array}{l}\text { lleating and Air Consitionlng, } \\
\text { Iastallaticn and Haintenance }\end{array}$ & $\begin{array}{l}\text { Skilled Onsite Mechanlcs, } \\
\text { Wet Systems }\end{array}$ & 350,000 & NLRA \\
\hline
\end{tabular}


Table 3-1. (continued)

\begin{tabular}{|c|c|c|c|c|}
\hline UNION & $\begin{array}{l}\text { GENFRAI. } \\
\text { JURISI) I ZTION }\end{array}$ & SKTILL AREAS & $S[Z E$ & $\begin{array}{c}\text { IEGAL } \\
\text { CUVERAGE }\end{array}$ \\
\hline $\begin{array}{l}\text { Roofers, iDamp end } \\
\text { Waterproof }\end{array}$ & $\begin{array}{l}\text { Roofing. Single Finfily to } \\
\text { Heavy Butidings--lew and } \\
\text { Retrofit }\end{array}$ & $\begin{array}{l}\text { Skilled Roofers of all types } \\
\text { of Roof ling }\end{array}$ & 50,000 & NLRA \\
\hline $\begin{array}{l}\text { Sheet Metal Wirkers, } \\
\text { International Assoc. } \\
\text { (SNWIA) }\end{array}$ & $\begin{array}{l}\text { Installation and Manufacturing, } \\
\text { Heating and Cooling Ducts }\end{array}$ & $\begin{array}{l}\text { Installers and Manufacturers } \\
\text { of A1r Ducts for Heating and } \\
\text { Cooling, Including Pumps-- } \\
\text { Also, Malntenance of Air } \\
\text { lleating and Cooling Units, } \\
\text { Pumps and Tilners }\end{array}$ & 160,000 & $\begin{array}{l}\text { NLRA } \\
\text { NRLAA }\end{array}$ \\
\hline
\end{tabular}




\author{
COMPOSITE SURVEY - SOLAR TECHNOLOGY \\ AFL-CIO SELECTED BUILDING TRADES COUNCILS \\ (Columns arranged in order of question in survey)
}

Key Code to Survey:

a. State (St): State in which council located.

b. Location (Location): Council location within state.

c. Significant Degree of Solal Sineigy Inulullation (sig), $V$ (very significant); S (significant); and N (not significant).

d. Installation of Solar Energy.Systems (Install): U (union installed); Non (nonunion installed); and Unc (uncertain).

e. Whare Solar Energy is used, What Type of Construction (Type): N (new construction; $R$ (rehal ur remodeling).

f. Extent of Solar Application in S/F (single family) $M / F$ (mulcifamily), SmC (small construction), and $\mathrm{LgC}$ (large construction): extent of applicarlum lenuted by $M$ (many), F (fpw), ., or $N$ (none).

g. What Jurisdictions are Involved in. Solar Energy Application (Jurisdiction): Carpenters (1); Electricians (2); Glaziers (3); Iron Workers (4); Plasterers (5); Plumbers (6); Pipefitters (7); Roofers (8); Sheet Metal Workers (9).

h. Jurisdictional Conflicts in Solar Technology (Con): N (no); Y (yes).

i. Is there Interest in Workshops on Solar Energy Installation (Interest): $\mathrm{Y}$ (yes); $\mathrm{N}$ (no). 
TABLE 3-4

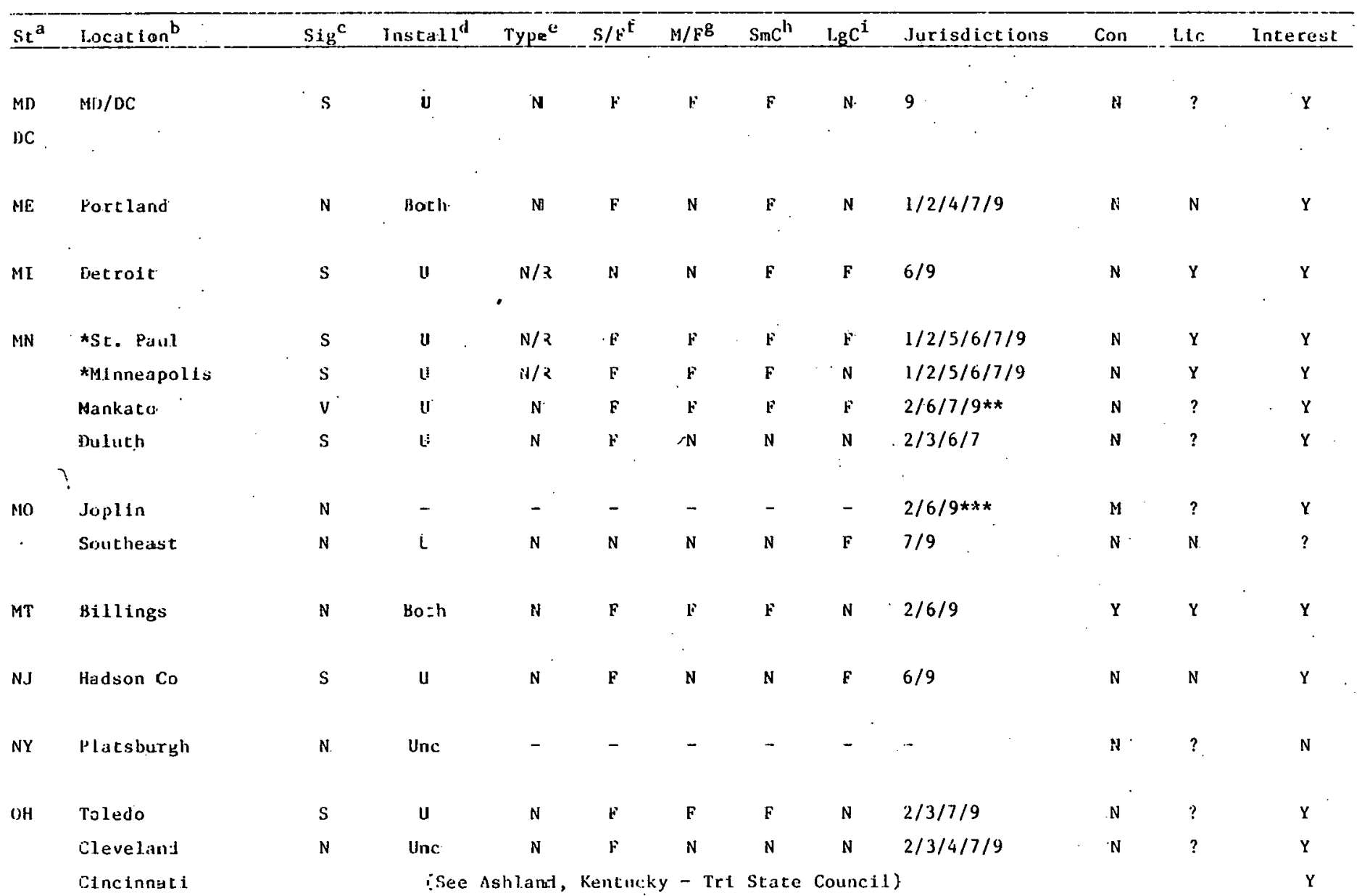


Table 3-4 (Continued)

OR

Portland

liugene

si)

'x

Austin

*houston

Ainar 1110

Texarkana

A2

xhoenix

ricson

imperial

Fresno

San Mateo

Orange Co

-San DLego

co

Statewide

DE

EI

orlando

*Gulf Coast

GA

*Atlanta

I.N

Indtanapolis

N. (Sec Survey Ste.2t)

Non $\mathrm{N}$

I!

N

N $2 / 3 / 4 / 6 / 7$

N

$\begin{array}{ll}\text { U } & \text { N } \\ \text { Li } & \text { N }\end{array}$

Unc

-

Both

Both

N

(n)

Non

Unc

u

Inc

N
N
N/SR
$?$
N

$N$
$N$
$?$
$k$

N

$N$

Non

N

Foth

$N / K$

(n)

r

$\mathrm{N} / \mathrm{K}$

N .

N

N $3 / 7,9$ 
Table 3--4 (Continued)

\begin{tabular}{|c|c|c|c|c|c|c|c|c|c|c|c|c|}
\hline LA & Des Molnes & in & Beth & 1 & in & $\mathrm{N}$ & $\mathbf{b}$ & $N$ & $7 / 9$ & iv & $Y$ & ? \\
\hline \multirow[t]{3}{*}{ KY } & lextingcon & $\mathbf{N}$ & Uac & $A$ & F & $\mathrm{F}$ & li & $F$ & $2 / 6 / 7 / 9$ & $N$ & $?$ & $Y$ \\
\hline & Loulsville & $\mathrm{N}$ & Unc & F. & $\mathbf{F}$ & $?$ & li & N & Unc & N & $?$ & $Y$ \\
\hline & $=$ & & & & & & & & & & & \\
\hline LA & Baton Rouge & $N$ & リ & $i$ & $\mathrm{~N}$ & $N$ & $\mathrm{~N}$ & F & $2 / 3 / 6 / 8 / 9$ & $\mathrm{~N}$ & $\mathrm{~N}$ & $\mathrm{~N}$ \\
\hline MA & \# Boscon & $\mathrm{N}$ & Bcth & $\mathbf{N}$ & $\mathrm{F}$ & $\mathrm{N}$ & $\mathrm{N}$ & $\mathbf{F}$ & $6 / 9$ & $\mathrm{~N}$ & $?$ & $Y$ \\
\hline \multirow[t]{2}{*}{ WA } & * Seattle & $v$ & u & $\mathrm{N}$ & $\mathrm{l}^{2}$ & $\mathbf{k}$ & M & $r$ & $2 / 3 / 6 / 9$ & $\mathrm{~N}$ & $\mathrm{~N}$ & $\mathrm{Y}$ \\
\hline & *Spokane & $s$ & U & $\mathbf{N}$ & F & $\mathbf{F}$ & $\mathbf{F}$ & $\mathrm{F}$ & $1 / 2 / 5 / 6 / 9$ & $\mathbf{H}$ & $\mathrm{N}$ & $\mathrm{Y}$ \\
\hline
\end{tabular}

* Interviews conducted personally

** Laborers

$\star \star \star$ Asbestos Workers

**** Asbestcs Workers 
$\checkmark$

THIS PAGE INTENTIONALLY LEFT BLANK 


\section{SECTION 4.0}

\section{IN-DEPTH ANALYSIS OF PRINCIPAL SOLAR-RELATED UNIONS}

As a result of the positive relations growing out of initial interviews and the Labor Leadership Workshop, SERI decided to continue building an effective communication base with the trade union community. A thorough understanding of the organization, structure, needs, and interests of the various unions involved or potentially involved in solar technology is necessary.

In-depth interviews were conducted with each of the unions that participated in the workshop or had an interest in further contact with SERI (even if the union did not participate in the workshop). The strategy involved conducting the in-depth interviews with the respective unions at the International Union Headquarters, if possible. The results of the interview would be combined with research on the constitutions, bylaws, and other organizational features of the union to provide an extended profile of the given union.

Interviews were conducted in International Union Headquarters in Washington, D.C., Detroit, Pittsburgh, and Denver. Interviews were kept informal and were permitted to range as widely as necessary to suit the convenience of both SERI and the respective union. General questions were suggested to the interviewee--both by mail and during the course of the interview--but they were not meant to limit the natural evolution of the interview. Generally, interviews took approximately 60 to 90 minutes to complete.

The interviewers suggested the following general areas for discussion to the participating union leaders:

- the work-force jurisdictions which your union encompasses;

- tho kind(s) of elupluyers wlth whlch your union contracts;

- the vertical level of authority which your union assumes in signing agreements--local, regional, state, and nationwide; and

- the kinds of training programs which your union supervises, initiates, holds under its own auspices, and engages in with other unions or with employers.

Specific ares of discussion were the following:

- if your union participated in the Labor Leadership Workshop on June 9, your reaction to the SERI workshop;

- your union's interest in solar technology--and its production and installation;

- a discussion of what you would expect or want from either SERI or the Department of Energy (DOE) on solar energy decisionmaking; 
- how your union publications--international union and state and local councils or unions--might best be utilized with regard not only to the interests of SERI and DOE, but of the union as well;

- the kind(s) of input that you would like to make to SERI, its publication, its staff, and its operations;

- how you feel your union is now influencing or can influence energy policy in the United States with the private sector? with the Congress? with state legislatures? with the White House? with governors of states? other places? and

what would you think your union's top priority would be if you were to emphasize how your union and SERI could best work together to achieve the goal of increasing the amount of solar technology that can or should be put to work lil the United Statoe in both the near and far distant future?

It should be noted that these discussion areas are not exhaustive of the types of questions and issues which arose during the course of interviews.

Almost unanimously, the labor leaders interviewed for this analysis were receptive to close relations with SERI. Indeed, several were enthusiastic about involvement of their craft in the solar energy field and they suggested various ways that SERI and the unions could further mutual objectives in the area of solar energy.

Al1 of the labor leaders indicated they would be interested in receiving newsletters, press releases, results of research studies, and articles for their publications from. SERI. Virtually all interviewed suggested the articles from SERI should address two types uf concerns: firet, the artirles should speak to the union member in terms of employment prospects for the union; secondly, and in the case of such unions as the Boilermakers and Teamsters where the short-range employment prospects for their union are limited, the articles should address the members as consumers. In both cases, the articles should be clearly written, devoid of "academese," not overly extensive, and aimed toward the question of how their union members benefit either as workers or as consumers.

Those leaders interviewed indicated that they would serve as contact points between their union and SERI on such matters as meetings, receipt of articles, participation in workshops, etc. There were also several instances in which the respondent wanted materlils routed through the geners 1 prosident of the union. In some cases, the respondent offered the names of others on the staff who would also be willing to participate in building strong relations with SERI.

Without exception, those labor leaders who had atteuded the Junc 9 Labor Leadership Workshop were favorably impressed with the meeting. Their favorable reaction was well established before the conference began. They appeared to be somewhat surprised that a quasi-governmental agency would go to such lengths--including preparatory visits--to keep the labor leadership informed, advised, and consulted. 
Most of the leaders interviewed felt there might be some jurisdictional problems involved in the effort of the unions to move into solar energy. None, however, seemed to feel the obstacles would be insurmountable. Additionally, several of the respondents believed that by confronting the question of the role of the unions in solar technology in the beginning, the possibility of painless resolution of any jurisdictional questions would be enhanced.

Most of the leaders interviewed believed that solar technology has a role in the country's energy future, and that solar technology should be developed as one phase of a multidimensional approach--coal, oil shale, conventional fuels, etc.--to the energy crisis. Though respondents saw a role for solar energy and are interested in being part of that role, some felt that the development of various other types of energy sources--nuclear, for example--would create far more jobs for their members than solar energy.

Virtually all of the leaders interviewed felt their membership did not have enough data about the various energy sources and problems, and this information lack is particularly marked in the area of solar energy. There are considerable misconceptions surrounding solar energy such as the feeling that solar energy cannot be useful in cooler, cloudier climates. Union members are not aware of the feasibility, the costs, and the benefits of solar energy. Indeed, in many cases, members are not certain an energy crisis exists, believing the "crisis" has been fabricated in part to increase the prices charged by major oil companies.

Union leaders noted that most of their locals are autonomous; some noted that the locals are very autonomous and sometimes ignored direction from their national leaders. Employer agreements and negotiations are usually handled at the local level in most of the crafts, and the agreements are forwarded to the international union. Of course, where national agreements are applicable (e.g., the Alaskan Pipeline, nuclear facilities, etc.) the agreements are consumated at the organization's national level.

Virtually all of the unions agree that the needed training of their members for work in the solar technology field would be a very minor adjustment in their present training programs. Of course, the adjustments needed may take some time to incorporate into training programs where joint management-labor apprenticeship councils operate. Some of the respondents saw the possibility of SERI being helpful in providing guidance on developments in solar energy and the kinds of skills union members may need to keep abreast of the developments. The Solar Energy Research Institute would help mold any future apprenticeship training prograu affecting solar technology by advising the unions of the kinds of skills needed in the future.

Several union leaders interviewed indicated that their crafts were receiving grants (through CETA, Job Corps, etc.) from the federal government for training programs. The Operating Engineers have been extremely successful in getting federal funding for training and education of their members. Union leaders strongly support governmental training programs within the established apprenticeship and pre-apprencticeship programe of the various unions. Some of the leader's interviewed felt that SERI may have a role in helping to bring appropriate government officials together with union leaders to discuss how the government can spend its training money more effectively. 
Several of the union leaders noted that SERI should educate the union and its members as to solar technology developments so that the union can determine if it has a role. In short, the respondents were saying that SERI now knows the union leaders and its members, but the unions and their members still are uncertain about solar energy and its future.

Several union leaders suggested alternative ways SERI might continue to build a close relationship with them. For example, almost all of those interviewed felt that SERI would be welcome to address national or regional meetings of their leaders, whether the attendees be national, regional, or local business agents. The respondents indicated they would be willing to keep SERI informed of their coming meeting dates and that normally they would have no problem in putting SERI on their meeting agenda. Other leaders indicated that SERI must impress upon union leaders the need for the councry to move strungly lu llie solar energy area so the leadership can communicate this view to their general membership.

All of the union leaders wanted to visit SERI and tour its facilities. They wanted future workshops or seminars if such activities would cover specific themes such as solar breakthroughs that might mean additional jobs and greater energy savings by their members.

Many of the smaller crafts are not involved in the National Energy Coalition. They do not have the resources to push one energy source over another in the Congress, the White House, or in the various states. But they are active through the AFL-CIO and the Building and Construction Trades Department. In addition, almost all of the leaders expressed concern and interest in becoming more deeply involved in policy on America's energy fucure.

Virtually all leaders interviewed--including those who are only related to solar technology in the long range--belleve their unions have a rule Lu play in solar technology's future, whether in production, distribution, installation, or as consumers. Furthermore, they are willing to modify their training programs, organizing programs, consumer education,etc. to permic the1r members to become involved in solar technology. Thus, (as an example) Robert Welch of the painter's union noted that if solar technology expands rapidly and the glaziers' union increases as a portion of their total union membership the union structure would probably be changed to reflect that growth and to represent it more adequately within the union.

Most importantly, the union leaders interviewed had not received enough detailed kowledge of the costs, benefits, obstacles, and employment prospects for solar energy to know how unions might relate to solar energy or how heavily the union might become involved. As far as they were concerned they wanted full involement, but they did not know what problems they would face in the future because of that involvment.

The following section provides a listing of the unions interviewed and pertinent statements made during the course of the interview. 


\section{SECTION 5.0 \\ UNIONS INCLUDED IN INTERVIEWS AND SELECTED COMMENTS}

\subsection{BOILERMAKERS, IRON SHIP BUILDERS, BLACKSMITHS, FORGERS, AND HELPERS; INTERNATIONAL BROTHERHOOD OF}

Solar technology would have to become extremely sophisticated and applicable at the heavy industrial level before the union would become deeply involved. Principal focus includes utilities and steel mills.

\subsection{BRICKLAYERS AND ALLIED CRAFTSMEN, INTERNATIONAL UNION OF}

The belief is that this union will become heavily involved in solar technology. Cited were such factors as heat-retaining walls and their insulation potential, thermal wells within walls, solar piping which runs through masonry, technologically improved brick for passive and active solar systems, and increased use of adobe construction. Research is currently being conducted with manufacturing organizations such as the Brick Institute of America for increasing the energy potential of fireplaces. Their view is that fireplaces will become increasingly popular and demand for them will increase as the country runs short of conventional fossil fuels and as the various areas of solar development progress.

\subsection{CARPENTERS AND JOINERS OF AMERICA, UNITED BROTHERHOOD OF}

It is conceivable that SERI could find that the carpenters can be involved directly in solar energy installations. For instance, a large union homebuilder(Pear1 Mack Construction Company) in Denver, because of the nature of the wording of the contract established between the general contractor and the subdivision developer (Montbello), used Carpenters and Iron Workers exclusively in panel installations.

\subsection{ELECTRICAL, RADIO AND MACHINE WORKERS; INTERNATIONAL UNION OF (IUE)}

"Our members have instructed us to focus on nuclear energy and promote the manufacture of nuclear components and the use of nuclear as the single most capable alternative available to America and the world."* The position of the union can best be defined as hard line.

\subsection{ELECTRICAL WORKERS, INTERNATIONAL BROTHERHOOD OF (IBEW)}

The Electricians see the possibility of building code problems as solar installations progress. For instance, even though the basic adaptions of

*George Collins, Legislative and Political Education Director. 
electrical connections and installations will be somewhat alike including the installation of pumps, the interconnections with solar technology--as the Construction Department of IBEW now views it--are likely to provide problems. This results principally from inadequacies in technology that produce leakages in wet systems or heat retention problems in the case of air systems. The Electricians do not feel that this will normally disturb their work, but it may result in building code problems.

\subsection{HEAT AND FROST INSULATORS AND ASBESTOS WORKERS, INTERNATIONAL ASSOCIA- TION OF}

"The development of nuclear energy provides the best possible energy source in terms of the union's employment prospects:"* They appear to feel little need for retraining additional skills which would be required by cheir menilbers in solar technology. Nonunion workers have virtually all of the residential market, perhaps half of the commercial market and less than $10 \%$ of the industrial market.

\subsection{LABORERS' INTERNATIONAL UNION OF NORTH AMERICA (LIUNA)}

The LIUNA now has industrial, construction, and service trade contracts in everything from shipbuilding yards to the packing industry, from candle manufacturing to prestressed and precast concrete, to goverminent contracts, and to the whole area of prefabrication related to plaster board, insulation, pumice, and aggregates associated with the cement industry. The union is heavily oriented and focused on prefabrication manufacturing. The LIUNA's greatest impact in solar technology would come if and when the technologies are mass produced.

\subsection{MACHINISTS AND AEROSPACE WORKERS, INTERNATIONAL ASSOCIATION OF (IAM)}

The union has recently been involved in setting up the newly established National Energy Coalition (Citizen/Labor Energy Coalition) along with six other unions. The Coalition has determined it will not get involved in the nuclear policy disputes. They intend, instead, to devote almost total effort to ". - promoting solar energy in concrete and practical terms . . "** before the President, the Congress, and all potentially effective elected and appointed public policy review and action centeris a every level of guverument. 'l'hey expect to lobby, tescify, and resedrcl prublem areas, and they intend to propose citizen action channels to reach their goals. The Machinists stand ready and willing to convert plants from their present military hardware budgets to solar hardware budgets. Solar technology provides labor intensive potential and continued job security. The Machinists adopt the same

\footnotetext{
*Joseph Zinser, Jurisdicational Director.

${ }^{* *}$ William W. Winpisinger, President.
} 
posture for themselves that the Coalition leadership has assumed: oil, gas, and coal are still the interim alternatives, but solar energy is the future.

\subsection{OPERATING ENGINEERS, INTERNATIONAL UNION OF}

Principally, this trade is comprised of two major skills: construction with emphasis on heavy equipment operation, and crane bulldozers; and Stationary Engineers, with emphasis on the operation of buildings, power plants, and air conditioning in major installations. It is the Stationary Engineer who operates principally at the industrial level, who will be most involved with solar technology's long-range future. To a considerable extent, their job entails the management of the energy process within large-scale enterprises and offices. The IBEW is a very large union and is dominant in many large utilities. The Operating Engineers are deeply involved with self-containing industries which have their own power plants, boilers, etc. These the Operating Engineers operate and maintain.

\subsection{OPERATIVE PLASTERERS AND CEMENT MASONS, INTERNATIONAL ASSOCIATION OF}

They feel that solar advances will involve cement and plaster both in passive and active systems. The union forsees involvement in solar technology principally at the industrial level. They are currently heavily involved in nuclear construction.

\subsection{PAINTERS AND ALLIED TRADES, INTERNATIONAL BROTHERHOOD OF}

It is the Glaziers that will become most heavily involved with solar technologies not only in the installation of the glass product but in the fabriction of solar products in shops. Painters and the other skills are only peripherally involved, if at all--as in the case where solar panels may require trim. From the selfish economic employment standpoint nuclear power houses provide far more jobs than does solar energy. Fifty to seventy-five painters would be occupied seven to eight years on work involving one nuclear powerhouse. Coatings for such facilities have become exotic and sophisticated to the point that the safety factor is also involved. Nuclear facilities also take constant maintenance, repainting, and many man-hours. Solar energy takes little or no maintenance once installed. The union is somewhat at a disadvantage in the solar technology field because the extent to which it gets work in solar technology depends largely on the extent to which their contractors sell that which is being installed.

\subsection{PLUMBING AND PTPF. FTTTING INDUSTRY OF THE UNITED STATES AND CANADA,} UNITED ASSOCIATION OF JOURNEYMEN AND APPRENTICES OF (UA)

To describe the jurisdiction, one might say that the union "does everything" in the heating and cooling or plumbing and pipe fitting industry. If skill is required, the $U A$ is the one involved whether it is installation, construction, maintenance, or servicing. Solar technology has the potential for tremendous growth in union work and einployment. 


\subsection{SHEET METAL WORKERS, INTERNATIONAL ASSOCIATION OF (SMWIA)}

The Sheet Metal Workers have been in the forefront of the solar industry. The coordination of solar installation and solar programs is now a very top priority of the union. Sheet Metal deals primarily with air systems, both at the manufacturing and installation levels. This is where the bulk of its jurisdiction rests. Sheet Metal is anxious to get a cost-effective application of solar energy and they want to shore up their already existing product line. They have developed their own solar training programs for their journeymen. Sheet Metal feels that the private sector normally does not respond to the urgency or the need of developing solar technology. However, they feel that they and other unions do understand and can help push the importance of developing and installing solar energy as quickly as possible. The Sheet Metal Workers are flexible. They are ready for anything that happens in the world of solar technology and are flexible enough to know what they should know and when they should promote it. They have taken two major steps which provide testimony to the commitment of the union to solar energy:

- the union has been put on record as guaranteeing the workmanship of any solar installation performed. by Sheet Metal Worker members, and

- the union is moving to establish a private satellite corporation (not for profit) to press for use of forced air climate control systems powered by conventional and alternate sources of energy.

\subsection{STEELWORKERS OF AMERICA, UNITED (USWA)}

The Steelworkers have set up their new Energy Education Pruject. Surveys of various segments of the membership have indicated that most workers feel that the so-called energy crisis is really phony and contrived.

The USWA is setting a precedent by converting their National Education Center for their members near Pittsburgh to solar energy, at least in part. More important, they are seeking ways and medus of euliling and aiding nombers to "do-it-yourself" in putting solar components of some kind in individual member's homes. They feel that this will not only bring the watter home to the member, but will be an example on every block in America where a steelworker has a home and has responded to the union's national initiative.

\subsection{TEAMSTERS, INTERNATIONAL BROTHERHOOD OF}

There are some points at which it is possible that solar technology--when and if an industrial phase were reached--would affect the Teamsters in terms of jobs. Some 200,000 of the members of the union are involved in construction in some respects (e.g., construction site, concrete, drivers, haulers, and the like). But this is probably a long-range possibility. 


\subsection{UNITED AUTO WORKERS (UAW)}

The UAW began installing solar equipment in its own facilities over four years ago. They are another principle member of the National Energy Coalition and are very active in the solar technology movement. The UAW feels that it has to have mass citizen involvement. They feel that union leaders must inevitably join their memberships with other organized groups in our society who share the concerns of the UAW on energy sources and who are willing to push hard to move the advance and use of solar technology much more rapidly. The UAW implements social action programs through Community Action Program (CAP). United Auto Workers Community Action Program is proposing a major national focus on solar technology at this time. They have long stood for definition by law of the transition from those activities of government that are not productive to those activities that are productive--from military hardware to productive (clean) energy products. United Auto Workers/Community Action Programs give direct personal and financial support to solar action and solar lobbying through the Center for Study of Renewable Resources. One of the UAW's four legislative priorities is activating the use of solar technologies.

\subsection{UNITED SLATE, TILE AND COMPOSITION ROOFERS, DAMP AND WATERPROOF WORKERS ASSOCIATION}

Most residential work is nonunion, consequently they are heavily involved in the industrial and commercial areas. A great deal of their work is involved in upgrading existing roofs as well as in new construction. Solar energy can be viewed as either providing additional work or elininating work altogether. If the required roof area were reduced by the addition of collector panels, then there would be a detrimental effect on employment. However, if the roof area were increased, as in the case of a saw-toothed configuration--which many commercial and industrial facilities are leaning toward--then there would be the very real possibility of tremendous growth and additional. work and employment opportunities. In addition, the Roofers can provide reflective or absorbent coatings on roofs for additional solar gain. This area would conceivably be another very large growth area for the Roofers. 
THIS PAGE INTENTIONALLY LEFT BLANK 


\section{APPENDIX A}

\section{NATIONAL LABOR LEADERSHIP WORKSHOP OVERVIEH}

\section{OPENING STATEMENTS OF WORKSHOP}

President Georgine opened the workshop with a welcome followed by introductory remarks by Secretary Beattie. Secretary Beattie stressed the desire of DOE and of SERI to foster good relations with organized labor in America's effort to cope with the energy challenge. He indicated that labor unions represent some 22,000,000 workers and their families; both DOE and SERI want to reach out to them. Secretary Beattie also explained that preliminary analysis suggests the potential creation of at least 150,000 jobs per year by solar and other energy alternatives by the mid-1980s.

The workshop, moderated by Herrick S. Roth, President of Herrick S. Roth Associates, Denver, looked at a series of concerns in an effort to illuminate the crucial question: "How can SERI and DOE best work with trade unions in the production, marketing, and installation of solar technology?" Roth indicated that in addition to the Bullding and Construction Trades invited to the workshop, the UAW, the Machinists, and the Steel Workers had been invited because of their concern about future alternative energy technologies.

The workshop discussion began with Walter Cosel (Solar Consultant, Sheet Metal Workers) delivering a statement on behalf of the union. Cosel explained that in the view of the Sheet Metal Workers, the Federal Government could spend its money more effectively by placing simple solar energy devices in buildings like libraries where people can see them. He exemplified the low visibility problem with the solarized Denver Bus Garage which serves the Regional Transportation District (RTD). Few if any people know it exists because of its location.

He criticized the Federal Government for failing to make solar systems--and the discussion of those systems--simple. Solar energy systems are not complicated; they are not a large departure from the ski1.1s needed for the conventional heating, air conditioning and ventilation (HVAC) industry. He noted that solar technology must have a backup conventional system which can supply all energy needs.

Referring to his belief that government and scholars have made solar techno1ogy far more complicated than necessary, he mentioned a 6 th grade class in Boulder, Colorado which has built a solar device that actually works. The public has been duped into thinking solar technology is extremely complex. The image of complexity has kept unions and consumers out of the solar technology area. Cosel strongly suggested that those involved with solar technology should use the language of the installer in their solar energy equipment instructions. Manufacturers can provide this instruction.

He recommended that SERI appoint a labor representative to its highest advisory body having major input in policy formation within SERI. The 1ahor representative should be picked by the unions. In addition, the Federal Government should focus funds to help solarize labor's training facilities and 
to help fund labor's training programs. Such expenditures give solar technology larger public visibility.

Unions such as the Sheet Metal Workers already have a four-year training program for their workers. To include skills designed for solar technology is simply a small addition to their ongoing training programs. "The main objective of the unions," asserted Cose1, "is to create an industry. Then we can resolve any problems us disputes growing out of the develnpment of that industry." But he warned that if President Carter's goal of having 2.5 million homes with solar energy by 1985 is to be achieved, the industry and unions must take chances.

To a considerable extent, his extended statement cet this tone and grnundwork for much of the remainder of the workshop. Many of the themes touched upon by r.nsel were discussed at greater length as the workshop proceeded.

\section{LABOR JURISDICTIONS}

The participants were asked if there are any present or foreseeable jurisdictional questions which might impede the abilily of the trade unions to enter the solar technology area. Addressing the jurisdictional question, President Georgine indicated that there dite some major mythe surrounding the Building and Construction Trades. One of those myths is that unions are not involved in the homebuilding industry; yet some $85 \%$ of the homes in California are union-built. Another myth involves the over-exaggeration of jurisdictional clashes in the Building and Construcliun Trades. Thece are seldom as severe as played up; they can alud liave been workcd out reasonably.

On the matter of firisdicllous, James Ehay (Painters and Allied Trades) indirater that their workers are fully capable of installing glass collectors. The jurisdictional agreement between the Sheet Metal workess alid the Plumbers and Fitters may be inappropriate since it makes no recogullion of the role of the Painters and Glaziers.

The Glaziers are heavily 1nvulved in the manufacture and instal.1ation of solar energy and they do not plan to get out of it said William Duval (Painters and Allied Trades). The Carpenters, observed Jimmy Jones, have d vital interest in solar technology develupuent and in juricdictional questions. Carpenters and their apprentices are trained to do framework, and they are ready to Iinstall sular energy today.

Richard Cox noted that if people are going to accept solar energy IL must be competitively priced and skillfully installed. Union leadership should cooperate among the several trades to bring the union movement into alternative energy sources. Unions, industry, and government must create an Industry. Solar energy was man's natural energy in early civilization, and now we have come full circle to the point where we must return to solar energy. The conference is a positive move toward the various groups working together. But the cost factor is the main consideration because as a consumer he and others must look at the price tag. 
Speaking from the viewpoint of the laborers, Marrion Parsons recalled that when modular housing came to the front, there were no conferences beforehand among the trades and the industry. Instead, there was just competition on an industrial basis. It would be advantageous if the general presidents of the several trade unions all met and worked out jurisdictional questions prior to deep involvement in another new technology. The general presidents are doing this now to a far greater extent.

Far more significant than jurisdictional questions, according to Allyn Paramenter (Plumbers and Fitters), in the development of solar energy is the rehabilitation of existing homes. "Rehab" and retrofit may well be myths. People may not be willing to pay $\$ 8,000+$ to add solar energy to their present conventional system. Therefore, it may be a misconception to think there are billions of dollars worth of work and jobs in the solar retrofit of homes. Retrofit does not appear to be a major market, and this constitutes the central problem facing solar technology. Because of the mobility of our population, the investment in retrofit may not be viewed as one which can reasonably be returned.

On the matter of jurisdictions and installation, Rob Livingston (SERI) asked if unions have problems with manufacturers wanting to install their own products. Parker (IBEW) indicated his union has agreements with manufacturers. The same holds true for the Painters and the Laborers.

Reflecting what appeared to be the general consensus among labor participants concerning jurisdictional disputes, Shay (Painters) declared that SERI cannot solve labor's jurisdictional problems. But SER.I can provide guidance, advice, and input into labor's role within the developing solar energy field.

\section{APPRENTICE AND JOURNEYMEN TRAINING}

David Harrington (Sheet Metal Workers) contended that for those persons already trained in the trades, as with the Sheet Metal Workers, a small number of hours added to an apprentice program or a refresher course for journeymen is sufficient. At present, Harrington explained, the Sheet Metal Workers have nine hours of solar training in their four-year apprenticeship program.

Parsons (Laborers) noted that all of the trades present in the workshop essentially agree. They find they can train their people in eight hours or so. All of the trades are looking at the same cluster of skills.

Paramenter (Plumbers and Fitters) agreed, pointing out that in their training program the little extra training which would be needed for apprentices can be easily done. On-the-job training and attitudes are the key; they are supplemented by classroom instruction. But most of the training is done on the job.

But Harrington also warned that one cannot simply take a person off the street and train him in two days for solar installation. There does not exist a basis to justify this since the four years of training which all Sheet Metal apprentices receive is missing. The worker installing solar equipment has to come from within the union movement or union infrastructure. Otherwise, a 
brief training program is inappropriate. In fact, the toughest task is the training of instructors.

Describing the training program of the Plumbers and Fitters (UA), Paramenter said that there are about 30,000 apprentices in the UA with some 1,200 to 1,500 instructors brought together annually for training at Purdue University. The faculty of about 160 at Purdue comes equally from the industry (such as Honeyweli), from elie UA, dud from the Purdue farulty. A similar program is carried on by the Sheet Metal Workers at Ohio State.

Generally apprentices are interested and want to learn as a result of the economic incentive. But one must exercise care in constructing the training program lest it be boring to journeymen. H1s unlull wuuld invitc SERI to help the union in its training of appreulices. The union will provide a training program or a training package, since the unions already licive that. But SERI can offer guidance and assistance in adapting a tralning pruglall tu solar energy.

Throughout the workshop, labor participants stressed that faulty installation--a distinct possibility when unskilled labor is used--is a central variable in the degree to which consumers accept solar devices. Responding to the question of what unions are doing to hold down faulty installation, Shay (Painters) answered that his union had no evidence of faulty installation from union installers. Similarily, Harrington (Sheet Metal Workers) indicated that his union had no evidence of this possibility simply because there has been no study on the extent of faulty installation by union members. Thus, the union does not know whether faulty installacion is by union or nonunion installers.

Responding to George Morgan's (SERI) question as to whether unions have installed solar technology on the1r owa lialls, mecting rooms, and farilities, John Yolton (UAW) said that the UAW has done so in several instances, including an olympic size swimming pool and other facilities such as a UAW Education Center. Many thousands of members and their famllies go through these solar facilities. The UAW's experiences with solar energy have been encouraging. In addition, the Auto Workers were very active in Sun Day. Youlton concluded his remarks by suggesting that a feacibility study nught to be done on all government buildings in terms of energy costs/benefits. If done for federal, state, and local governmental buildings it would hopefully create the necessary demand to cause the mass-production ball to start roliing.

Questinning the DOE approach to installation and training of installers, Robert G. Welch (Painters and Allied Trades) recalled that the Butldluy diud Construction Trades were the hardest hit by the most recent recession. It seems to be a contradiction that the federal government is duplicating labor's efforts to train unskilled workers in technology and wasting millions in doing it. Instead of the federal government giving money to states for CETA (which is basically nonunion political patronage) the money should go to union training and jobs.

Duval (Painters and Allied Trades) wondered whether our main interest should be energy conservation--that is, to save energy through use of solar, technology--or should it be to put unemployed people to work?. If this is 
true, the solar industry could be ruined. Union workers are already trained and skilled for the installation of solar devices, and many of these workers are unemployed. If DOE were to use them, rather than attempting to quickly train the unskilled for work in the solar field, the solar industry would be advanced. Illustrating the point, Cosel (Sheet Metal) said that in April 1978, he had been approached by DOE representatves to set up a "quickie" solar course to teach people off-the-street about solar installation.

To these comments, Lawnie Taylor (DOE) responded that the central thrust is "economic development." Energy conservation is part of that and solar energy is one of the vehicles. But economic development is the key, and unskilled poor in urban cities are the focus.

\section{THE VARIOUS SOLAR ALTERNATIVES}

Moving from the discussion of solar heating and cooling, the participants briefly discussed other solar alternatives. Michael Collins (Operating Engineers) observed that the interest of his union members lies with larger installations. He noted that the union is very interested in solar energy as it becomes developed for central solar facilities, and that communication in meetings such as the workshop is very beneficial for that purpose.

Endorsing this view, Vincent O'Reilly (IBEW) indicated that some projects have been developed experimentally along the line of central facilities with IBEW work in New Mexico and California. Basically, they involve the concentration of the sun's rays on a boiler. O'Reilly viewed the effort as having good possibilities. Still addressing central facilities, Henry Gertz (Boilermakers) indicated that his people are caught in-between. They know that solar central facilities may well come, but they are not yet certain what to do about it.

Commenting on the various solar alternatives, Paul Rappaport (SERI) explained that SERI is interested in all phases of solar technology. That includes central facilities, photovoltaics, wind, bionass, geothermal, and other aspects of solar technology. In addition, SFRI has a program aimed at universities and education; is starting a solar energy data collection bank system; already has a technology commercialization and marketing section; and is interested in international objectives including joint foreign programs, foreign markets, and other international possibilities.

President Edward Carlough (Sheet Metal Workers) offered the observation that there is a large rural market for solar energy. He thinks that there is sufficient space and less worry about aesthetics in rural areas. In Carlough's opinion, SERI should look at the agricultural and rural application of solar energy particularly the matter of process heat for the agricultural industry. 


\section{LABOR/SERI COMMUNICATIONS}

Moving to the theme of communication with unions, Dana Moran suggested that a way should be found to inform organized labor of what is happening with all alternate energy technologies. For example, Moran observed that a column or article on solar technology in union publications would be very useful. In addition, the message could be tailored to each jurisdication so that it would be of maximum utility to the reader. In Llils way, GERI, the Rogional solar Centers, and the unions could use existing channels of communication for disseminating data and information.

Union representatives reacted favorably to Moran's suggestion that union publications be used as a communications vehicle between SERI and labor's rank-and-f1le members. P1ck1ng up the communicntion theme, Cose1 (Shept. Metal Wnrkers) reiterated his earlier recommendation that sumeute representing labor and selected by labor be on an advisory board or body a L Llie lifgliei tihelono of SERI to participate in policymaking and to keep labor informed. To this recommendation, Secretary Beattie (DOE) also suggested chat the trade unions lobby governors of the states to put labor people on governing boards involving solar technology in the various states and regions.

On the matter of communication, Cox (Carpenters) noted that in terms of communicating with the trades, international trade papers would provide SERI space for gett1ng their message across. All unions have some responsibility--whatever their different interests--to help build the solar industry and to help SERI get its message across would be one way to do so.

Iliustrating labor's desire to parlicipate, Prcoident Carlough (Shept Metal Workers) related an anecdote about the U.S. Senatur who admonished former President Lyndon B. Johnson with the comment, "Just once I would like to be in on the takentf inscead of just at the craoh landing." This, President Carlough indicated, is how labor often feels and why such activities as a communication workshop are useful. Carlough noted that though different unions have different interests, there is not as much fragmentation and conflict as is commonly assumed. He further advised that there is no such thing as "quickie" training, whether it is a plumber or any other trade. In that direction, he explained, lies disaster. President Carlough suggested that labor wants input into SERI at an early point, and the trades want SERI input into labor in the salue fashion.

\section{LICENSING AND STANDARDS}

Turning to the question of licensing and standards, Parker (IBEW) explained that electricians invarlably have codes from state and local government. National electrical codes pertain to virtually any kind of electric installation, whether it be solar or any other. Parker would like to see the solar industry set standards. 
Morgan (SERI) pointed to Florida legislation which requires licensing of solar energy installers. Harrington (Sheet Metal Workers) advised that no separate solar licensing is needed. Existing licensing--that is, the present HVAC system of licensing individuals--can also be sufficient for solar technology, once it is required that those licensed be competent in solar energy installation. Solar technology, after $a 11$, is just an extension of HVAC skills. All that is necessary is to test in such a fashion as to giving a solar dimension to an HVAC license.

Secretary Beattie (DOE) observed that there are really two matters at issue: first, standards have to do with the quality of the equipment, while second, codes have to do with work performance and what happens when the equipment is put on something (i.e., installation). DOE is working on this; but DOE will not dictate standards and codes. DOE is, however, moving to accredit testing laboratories to look at equipment and say which solar collectors are acceptable in terms of meeting certain criteria. In addition, code writing groups (such as NCSBCS, BOCA, etc.) are meeting under DOE aegis. Most of these groups feel codes are needed for solar energy. DOE has to get feedback from unions to find out what they think about standards and codes.

In commenting about codes and standards, Yolton (UAW) warned that if these codes and standards are overly restrictive, they can often serve as a barrier to a new industry. For example, the opponents of solar energy could use them to restrain and inhibit the development of solar technology.

Thinking that corles are not just "make-work," Parker (IBEW) contended that codes serve a consumer protection function. Recognizing that a balance must be reached, he was nonetheless happy to hear that the Federal Government also believes codes serve a purpose. He remarked that the Department of Housing and Urban Development (HUD) appears to be watering down codes and standards.

\section{TUE NATIONAL ENERGY COALITION}

During the course of the workshop, Cosel (Sheet Metal Workers) referred to the newly created National Energy Coalition. He indicated that there are now 15 unions represented in the Coalition, and the Coalition has a "solar energy task force." Barbara Shailor (Machinist representative at the workshop, and a staff member for the task force), should be contacted regarding the work of the task force. Rappaport responded that SERI would definitely take advantage of that pipeline of communication. It was observed by the gathered participants that the task force may be the key to communication since the representation spans important and concerned unions involved in solar energy.

In speaking briefly of the Coalition, President Carlough (Sheet Metal Workcrs) mentioned that President William Winpisinger of the Machinists has been the moving force behind the creation of the Coalition. The Coalition is a broadbased group, spanning many unions and interested parties. The varied interests represented in the Coalition have often been at each others throats on the question of nuclear energy. Their goal is to help shape energy policy in the search for alterative energy sources. In this, their interest is common. There are 18 members on the Board of Directors, including Presidents Carlough, Winpisinger, Fraser (UAW General President), and McBride (Steel 
Workers General President). Six of the eighteen Board member's are union leaders.

President Carlough explained that the National Energy Coalition funds the task force on solar energy, and the unions are providing staff. The Coalition will operate in several substantive areas, including legislative (federal, state, and local) as well as in the field of consumer protection. 
Table A-1: LABOR PARTICIPANTS AT WORKSHOP

Robert Georgine

Henry Gertz

Richard Cox

E. Jimmy Jones

Lynn Kinter

Robert J. Holton

Melvin H. Roots

James J. Boyle

John E. Hauk

A1 Lake

Richard Bailey

Michael Collins

William McBride

Vincent O'Reilly

J. M. Parker

Joseph P. Zinser

James R. Sheets

Marrion Parsons

Barbara Shailor
President, AFL-CIO Building and Construction Trades Department

BOILERMAKERS

Assistant Director, Construction
Division

CARPENTERS

Assistant to General President

Assistant to General President

Contractor

CEMENT MASONS

General Secretary-Treasurer

Executive Vice President

Vice President

International Representative

ENGINEERS

Assistant to General President

Director of Jurisdiction

Assistant Director of Education and Training

IBEW

Assistant to the President

Director, Utility Department

Director, Construction and Maintenanse Department

INSULATORS

Jurisdictional Director

\section{LABORERS}

Research Director

Training Director

MACHINISTS

Energy Consultant, National Energy Coalition 
Table A-1 (cont'd)

\section{PAINTERS}

William A. Duval

Robert G. Welch

Jàmes Shay

Allyn Paramenter

Vincent Garito -

Edward J. Carlough

Dave Harrington

Walter Cose 1

Nick Lamb

Judy Lerner
General Vice President

Special Assistant to General President

Director of Jurisdiction

PLUMBERS AND FITTERS (UA)

Director of Training

ROOFERS

International Ropresentative.

SHEET METAL

General President

Training Di,rector

Solar Consultant

Assistant

Assistant

UAW (AUTO WORKERS)

John YulLuI

Administrative Assistant, Department of Conservation

U.S. DEPARTMENT OF ENERGY PARTICIFANTS AT WORKSHOP

Donald Beattie

Acting Assistant Secretary for Conservation and Solar Applications (C\&SA)

Lawnle Taylor

Technology Transfer, C\&SA

Norman Selzner

Manpower Assessment

William Tucker

Division of Manpioer

SOLAR ENERGY RESEARCH INSTITUTE PARTICIPANTS AT WORKSHOP

Pau1. Rappaport

George Morgan

Joe Carlson

Helen Barker

Dana Moran

Bert Mason

Rob Livingston

Julie Riley

GEORGE MFANY CENTER FOR LABOR STUDIES--June 9, 1978 


\section{APPENDIX B}

\section{LABOR LEADER CONTACTS}

During the course of this project, SERI staff has had frequent opportunity to speak with and gauge the interest of a considerable number of labor leaders--whether at the national, regional, state, or local level--on their union's present and future relationship to solar energy. Periodically, SERI has received extended lists of those labor leaders contacted so that we would be in a position to maintain ongoing relations with them.

At present, work is underway for both Northeast and Mid-American regional workshops. Planning for the workshops has led to a considerable expansion of the firm's address files of labor leaders in these regions who have expressed interest in solar energy. It can be expected that continued preparation for the workshops and the actual workshop proceedings will reveal additional names which should become a part of SERI's permanent files.

SERI is presently compiling and consolidating such lists, with completion of a total, master list expected in mid-January 1979, shortly after the MidAmerican conference.

Attached in this appendix are abbreviated 1 ists already furnished to SERI. In addition, there is a compilation of major Labor Education Program Centers around the country and principal resource persons responsible for "Labor Education and Apprenticeship-Journeymen Training Programs" in unions most affected by solar energy. 
BOILERMAKERS, IRON SHIP BUILDERS, BLACKSMITHS, FORGERS AND HELPERS, INTERNATTONAL BROTHERHOOD OF

New Brotherhood Building

8 th Street at State Avenue

Kansas City, Kansas 66101

(913) $371-2640$

LEALERSHIP/CONTACT

Harold J. Buoy,

President

PUBLICATTON

Boilermakers-Blacksmiths Reporter

592 New Brotherhood Building

Henry Gertz,

Assistant Director

Construction Division

Kansas City, Kansas 66101

(913) 371-2640

Editor: Harold J. Runy, Assistant

Editor: Leona Nichols, Managing

Editor: Michael Wood

Ponehly Newupapar: Circulntion, 133,500

\title{
MEMBERSHIP
}

170,000

INTERVIEW CONDUCTED WITH

Henry Gertz,

Assistant Director

Construction Div1sion

BRICKLAYERS AND ALLIED CRAFTSMEN, INTERNATIONAL UNION OF

815 Fifteenth Street, N.W.

Washington, D.C. 20005

(202) 7833788

LEADERSHIP/CONTACT

Thomao F. Murphy,

President

PUBLICATION

Journa 1

815 Fifteenth Street, N.W.

Merlin Taylor, Assistant to the

President

Washington, D.C. 20005

Editor: John T. Joyce

Circulation: 70,000

\author{
MEMBER.SHTP \\ 160,000 \\ INTERVIEW CONDUCTED WITH \\ Merlin Taylor, \\ Assistant to the \\ President
}




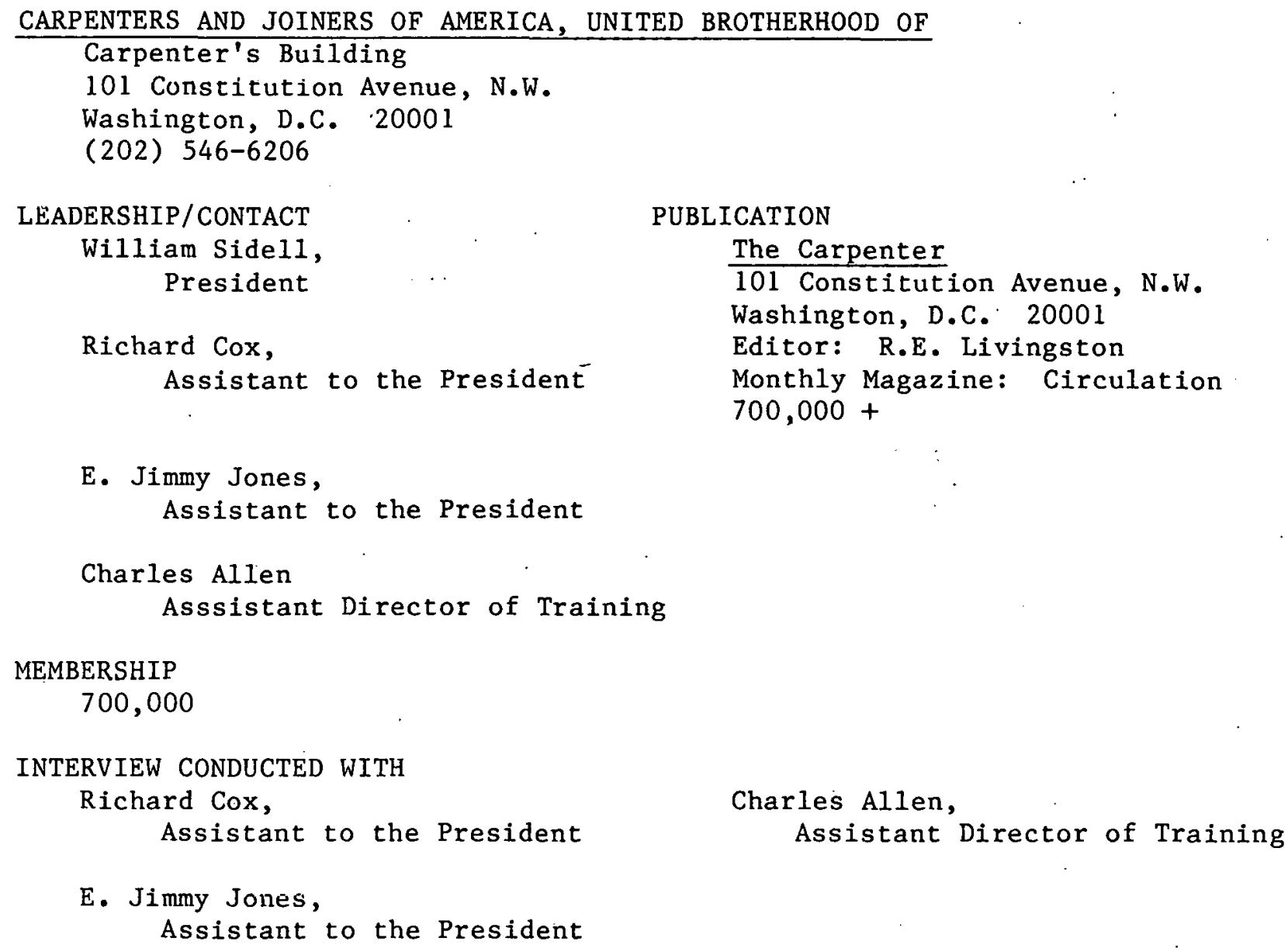

E. Jimmy Jones, Assistant to the President

Charles Allen

Asssistant Director of Training

MEMBERSHIP

700,000

INTERVIEW CONDUCTED WITH

Richard Cox, Assistant to the President

Charles Allen, Assistant Director of Training

E. Jimmy Jones,

Assistant to the President

ELECTRICAL, RADIO AND MACHINE WORKERS, INTERNATIONAL UNION OF (TIIF)

$112616 \mathrm{th}$ ST., N.W.

Washington, D.C. 20036

(202) 296-1200

LEADERSHIP/ CUN'TACT

David J. Fitzmaurice,

President

George Collins,

Legislative and Political

Education Director
PUBLICATION

IUE News.

$\overline{112616 \mathrm{th}}$ St., N.W.

Washington, D.C. 20036

Editor: David J. Fitzmaurice:

Managing Editor: Gerry Borstel Monthly Newspaper: Circulation, $300,000+$

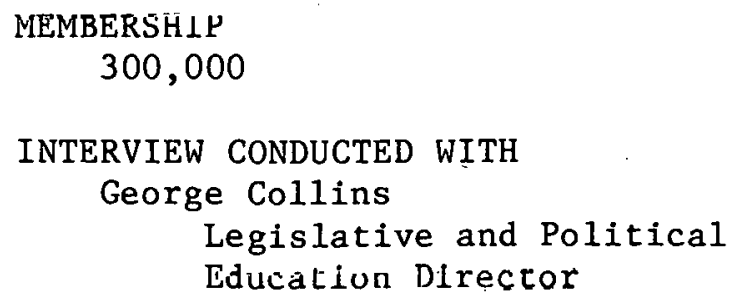


ELECTRICAL WORKERS, INTERNATIONAL BROTHERHOOD OF (IBEW)

1125 Fifteenth Street, N.W. Washington, D.C. 20005

(202) 833-7000

LEADERSHIP/CONTACT

Charles H. Pillard, President

William McBride, Assistant to the President

Vincent 0'Reilly, Director, Utility Department

J. M. (Kim) Parker, Director, Construction and Maintenance Department

\section{MEMBERSHIP}

$880,000+$

INTERVIEW CONDUCTED WITH

Vincent O'Reilly

Director, Utility Department

J. M. (Kim) Yarker

birector, Cumstiction and

Maintenance Department
PUBLICATION

IBEW Journal

1125 Fiftepnth Street, N,W, Washington, D.C. 20005

Editor: Charles H. Pillard Managing Editor: Robert W. McAlwee Monthly Magazine: Circulation, $1,000,000$

HEAT AND FROST INSULATORS AND ASBESTOS WORKERS, INTEKNA'ITUNAL ASSOCIATION ON

505 Machinists Building

1300 Connecticut Avenue, N.W.

Washington, D.C. 20036

(202) 758-2388

LEADERSHIP/CONTACT

Andrew T. Haas,

President

Joscph P. Zinser,

Jurisdictional Director

MEMBERSHIP

22,000

INTERVIEW CONDUCTED WITH

Joseph Zinser

Jurisdictional Director 
IRON WORKERS, INTERNATIONAL ASSOCIATION OF BRIDGE, STRUCTURAL AND ORNAMENTAL

1750 New York Avenue, N.W.

Washington, D.C. 20006

(202) 872-1566

LEADERSHIP/CONTACT

John H. Lyons,

President

Robert McVay,

Director of Jurisdictions
PUBLICATION

The Ironworker

1750 New York Avenue, N.W.

Washington, D.C 20006

Editor: John H: Lyons

Managing Editor: Bill Lawbaugh

Monthly Magazine: Circulation, 116,277

\section{MEMBERSHIP}

100,000

LABORERS', INTERNATIONAL UNION OF NORTH AMERICA (LIUNA)

905 Sixteenth Street, N.W.

Washington, D.C. 20006

(202) 737-8320

LEADERSHIP/CONTACT

Angelo Fosco,

President

W. Bernie Reed,

Secretary-Treasurer

Joe Short,

Director of Education

Marrion A. Parsons,

Director, Laborers International

Union Training Program

Lou Ellison,

Director of Industrial Contacts

James R. Sheets,

Research Director

\section{PUBLICATION}

The Laborer

905 Sixteenth Street, N.W:

Washington, D.C. 20006

Editor: Angelo Fosco

Monthly Magazine: Circulation, 600,000

MEMBERSHIP :

750,000 
INTERVIEW CONDUCTED WTH
W. Bernie Reed,
Secretary-Treasurer
Joe Short, Director of Education
Marrion A. Parsons, Director, Laborers Interna-
Lou Ellison, Director of Industrial tional Union Training Program Contracts

MACHINISTS AND AEROSPACE WORKERS, INTERNATIONAL ASSOCIATION OF (IAM)

1300 Connecticut Avenue, N.W.

Washington, D.C. 20036

(202) 785-5200

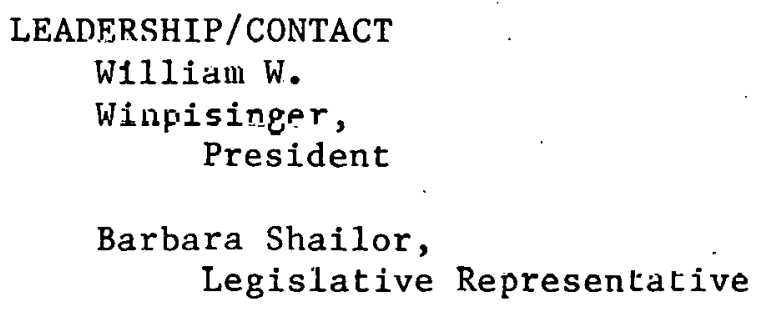

OIL, CHEMICAL AND ÁTOMIC WORKERS, INTERNATIONAL UNION (OCAW)

P.0. Box 2812

Denver, Cnlorado 80201

(303) 893-0811

LEADERSHIP/CONTACT

A. F. Croepiron, President

Tony Mazzocchi, Vice-President

\section{MEMBERSHIP}

200,000

\section{PUBLICATION}

The Hachinist

1300 Connecticut Avenue, N.W. Washingtuin, D.C. 20036 (202) 785-2525 Editor: Dean $K$. Rullı Monthly Newspaper: Circulation, 754,000 


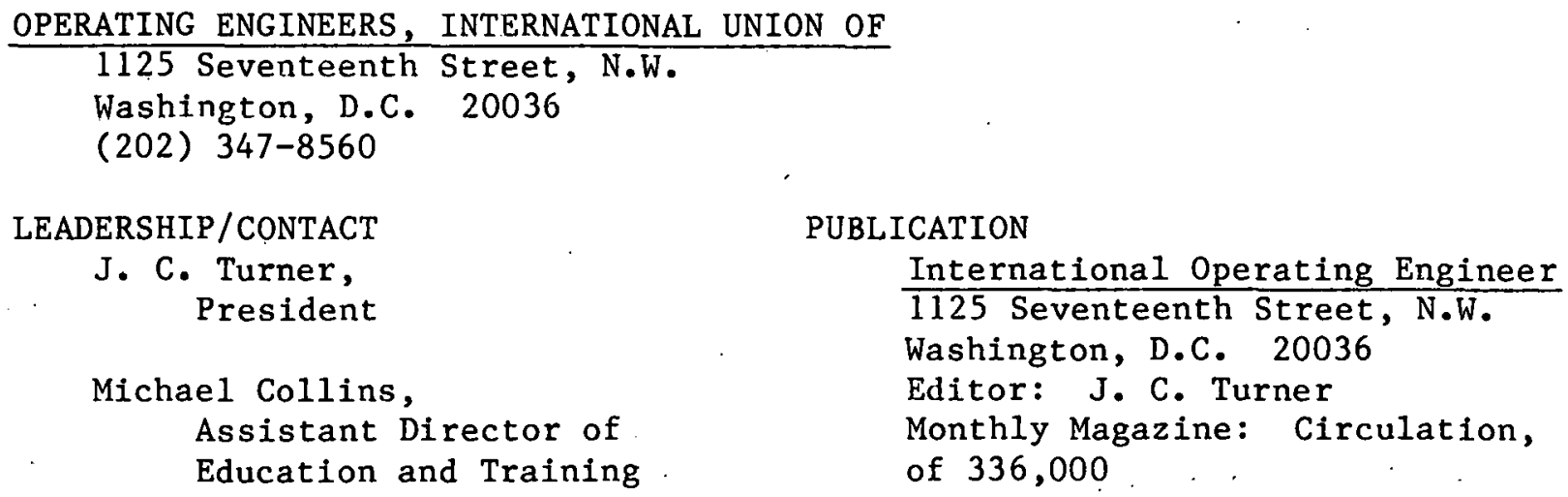

Al Lake, Assistant to the General President

Richard Bailey

Director of Jurisdiction

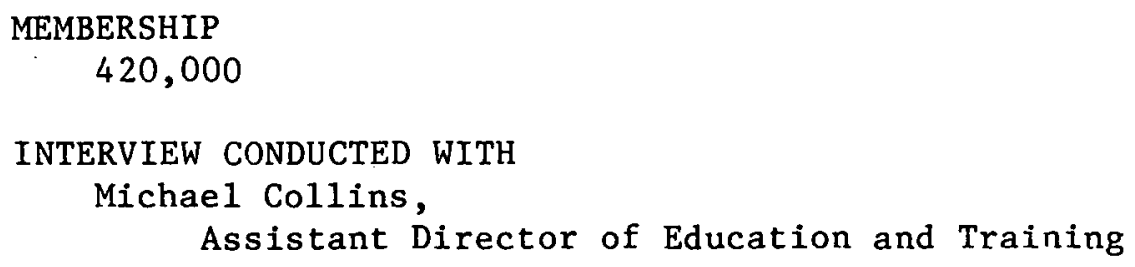

\section{LEADERSHIP/CONTACTT}

Joseph T. Power, President

James J. Rnyle, Vice-President

Melvin H. Roots, Executive Vice-President

Robert J. Holton, General Secretary-Treasurer

John F. Hauck, International Representative
PUBLICA'ILN

The Plasterer and Cement Mason 1125 Seventeenth Street, N.W. Washington, D.C. 20036

Editor: Joseph T. Power Monthly Magarine: Circulation, 65,000

\section{MEMBERSHIP}

100,000 
SHEET METAL WORKERS, INTERNATIONAL ASSOCIATION (SMWIA)

United Unions Building

1750 New York Avenue, N.W.

Washington; D.C. 20006

(202) 296-5880

LEADERSHIP/CONTACT

Edward J. Carlough, President

Larry Cassidy, Assistant to the General

President

Walter J. Cosel, Solar Consultant Sunergy Power Ltd. 400 West Main Street Babylon, New York 11702 (516) 587-0684
PUBLICATION

Sheet Metal Workers Journal. 1750 New York Avenue, N.W. Washington, D.C. 20006 Editor: David S. Turner Montly Magazine: Circulation, 160,000

Dave Harrington, Training Director

National Training Fund

Sheet Metal and Air Conditioning Industry

1900 L. Street, \#405

Washington, D.C. 20036

\section{MEMBERSHIP}

160,000

INTERVIEW CONDUCTED WITH

Walter J. Cose1, Solar Consultant

STEEL WORKERS OF AMERICA, UNITED (USWA)

Five Gateway Center

Pittsburgh, Pennsylvania 15222

(415) 562-2666

LEADERSHIP/CONTACT

Lloyd McBride,

President

Jim Smith, Assistant to the President
PUBLICATION

Steel Labor

Five Gateway Center Pittsburgh, Pennsylvania 15222

Editor: Raymond W. Pasnick

Monthly Newspaper: Circulation, $1,550,000$

Jack Eckman,

Program Director of Political

and Legislative Artion 
MEMBERSHIP

$1,500,000$

INTERVIEW CONDUCTED WITH

John Yolton, Administrative Assistant to the Vice-President for Environmenta1, Energy and Consumer Affairs

UNITED SLATE, TILE AND COMPOSITION ROOFERS, DAMP AND WATERPROOF WORKERS ASSOCIATION

1125 Seventeenth Street, N.W.

Washington, D.C. 20036

(202) 638-3228

LEADERSHIP/CONTACT

Roy E. Johnson, President

Vince Garito, International Representative

PUBLICATION

The Journeymen Roofer \&

Waterproofer

1125 Seventeenth Street, N.W.

Washington, D.C. 20036

Editor: Dale Zusman

Monthly Magazine: Circulation, 21,000

MEMBERSHIP

50,000

INTERVIEW CONDUCTED WITH

Joseph Bisse11,

Assistant to the General President 
ARIZONA

Dudley Brown, Business Manager Phoenix Building and Construction Trades Coninri1, AFI-Cin 1841 North 24 th Street, Suite 7 Phoenix, Arizona 85008

C. W. Upchurch; Business Manage $r$

Southern Arizona Building and Construction Tradeo Council 2030 E. Broadway, Sulle 213 Tucson, Arizona 85719

Ivan Smith, Chairman Walter Campbe11, Chairman Tonto Apache Tribal Council Payson, Arizona 85541

\author{
Marvin E. Smith, Asbestos Workers \\ Glynn Ross, IBEW \\ Inhn de Cast.rn; IBEW \\ Vernon McBride, Plumbers and \\ Fitters \\ Henry Olea, Plumbers and Fitters \\ Jim Jangula, Roofers \\ Pete McGhee, Plumbers and Fittèrs \\ Don Procise, Roofers \\ Fied Bruwn, Executive Director \\ Arizona State Commission of Solar \\ Energy \\ Arizona State University \\ Tempe, Arizona \\ Steve Leneberg \\ Treetop Enterprises \\ Payson, Arizona 85541
}

\section{CALIIFORNIA}

Colin C. Bell, Secretary and Business Manager

San Diego County Building and Construction Trades Counc11 3909 Centre Street, Room 212

San Diego, California

John J. Donlon, Business Manager Building and Construction Trades Council of Colorado 1540 Eutersun itreet

Denver, Colorado 80218

George Löf, Chairman of the Board Solaron Corporation 720 South Colorado Boulevard Denver, Colorado 80222
Dexter Levy, Plumbers and Fitters Horace Sealing, Cement Masons

Gregory Maynard

Southwest Energy Management, Inc. 8290 Vickers Street, Suite B

San Diego, California 92111

\section{COLORADO}

Darold Fox, Training Coordinator Sheet Metal Workers Training Fund 688 Bryant Street Denver, Colorado 80204 


\section{DELEWARE}

Theodore W. Ryan, President

Wilmington Building and Construction Trades Council

1620 Wilmington Road

New Castle, Deleware 19720

FLORIDA

Morris Blake, Business Manager

Florida Gulf Coast Building and Construction Trades Council

3505 Central Avenue

Tampa, F1orida 33603

\section{GEORGIA}

George Caude11, Business Manager

North Georgia Building and

Construction Trades Council

250 Tenth Street, N.E., Suite 106

Atlanta, Georgia 30309

\section{MISSOURI}

Robert Mills, Program Director

Kansas City Chapter of SMACNA

4218 Roanoke, \#301

Kansas Lity, Missouri 64111

\section{MASSACHUSETTS}

Charles H. Burkhardt, Executive Vice-President

New England Fuel Institute 20 Summer Street

Watertown, Massachusetts 02172

William J. Cleary, President

Massachusetts State Labor Council, AFL-CIO

6. Beacon Street, Suite 720

Boston, Massachusetts 02108

\section{MICHIGAN}

John Girolamo, International

Organizer

Sheet Metal Workes International

Association

25444 Larkins Court

Southfield, MLchlgan 48075
William L. Styles, Business Manager

Sheet Metal Workers Local 80

32700 Dequindre

Warren, Michigan 48092 


\section{MICHIGAN (cont'd)}

Al Thiel, Training Director

Sheet Metal Workers Local 80 Training Center

32700 Dequindre

Warren, Michigan 48092

\section{MINNESOTA}

Donald Anderson, Director

Mid-America Solar Energy Complex

1256 Trapj Rúd

Egan, Minnesota 55121

Daniel W. Gustafson, SecretaryTreasurer

Minnesota AFL-CIO

175 Aurora Avenue

St. Paul, Minnesota 55103
Leonard Biunias, Business Manager

Minneapolis Building and Construction

Tradco Council

312 Central Avenue; Room 556

Minneapolis, Minnesota 55414

Richard C. Radman, Secretary and Bus1ness Manager

St. Paul Building and Construction

Trades Council

411 Main Street

St. Paul, Minnesota 55102

OREGON

Earl B. Kirkland, Secretary

Columbia-Pacific Oregon Building and Construction Trades Council

304 Portland Labor Center

201 S.W. Arthur Street

Portland, Oregon 97201

TEXAS

Robert T. Stringer, President Wayne Aldridge, Secretary and Business Manáger

Austin Building and Construction

Trades Council.

400 Josephine Street

Austin, Texas 78704

LeMoine Pitman, Business

Representative

Sheet Metal Workers Local 67

Route 1, Box $20 \mathrm{C}$

Spicewood, Texas 78669
M. A. (Pee Wee) Graham, Executive Secretary

Huuslun-Gulf Cuast Building and

Construction Trades Council

2704 Sutherland

Houston, Texas 77023

Robert Boyd, Plumbers and Fitters

Jackie St. Claire, President

Texas Building and Construction

Trades Council

1106 Lavaca, Suite 204

Austin, Texas 78701 


\section{WASHINGTON}

G.lenn Arnold, Business Manager

Sheet Metal Workers

IBEW Building

2700 First Avenue

Seattle, Washington 98121

Darre1 D. Grant, Secretary

Northeastern Washington-Northern

Idaho Building and Construction

Trades Council

102 E. Boone, Room 10

Spokane, Washington 99202
William E. Crooke, Business Manager

Seattle Building and Construction Trades Council

Suite 211, IBEW Building

2700 First Avenue

Seattle, Washington 98121 .

John Ober, Executive Secretary

SMACNA, Western Washington Region

1200 Westlake Drive, North

Seattle, Washington 98109

WASHINGTON, D.C.

Fred K. Hoehler, Jr.,

Executive Director

George Meany Center for Labor

Studies

10000 New Hampshire Avenue

Silver Springs, Maryland 20903

Peggy Jarman, Director Sales

The Hay-Adams

Sixteenth and $\mathrm{H}$ Streets, N.W.

Washington, D.C. 20006
Janis Strange, Registrar

George Meany Center for Labor Studies

10000 New Hampshire Avenue

Silver Springs, Maryland 20903 


\section{LABOR EEUCATION PROGRAM CENTERS}

(Courtesy of Bill Rentfro, Director; Al Wickman, Associate Director;

Center for Labor Education Research, University of Colorado-whose names may be. used in any of these contacts)

\section{University of Illinois}

Ron Peters, Coordinator of Labor Programs

Institute of Labor and Industrial Relations

University of Illinois

504 E. Armory

Champaign, Illinois 61820

(217) 333-0980

Stan Rosen, Courdinator

Chicago Office, University of Illinois

Labor Programs, Institute of Labor and Industrial Relations

1315 SEO Building

P.0. Box 4348

Chicago, Illinois 60680

(312) 996-2623

University of Indiana

D. W. "Whit" Murphy, Director

Division of Labor Studies

Univereity of Indlana

$3120 \mathrm{~N}$. Park.

Bluomington, Indiana 47401

(812) 337-9082

(NOTE: l'here are four principal satellites at other university and college locations related to the higher education system of the State of Indiana but Murphy or his nffice can lead you to any of them including those in the South Bend, Lafayette, Indianapolis, and Evansville diteas.)

Iniversity of Iowa

Mark Smith, Program Virector

Labor Education Program

Industrial Relations Institute

Phillips Hall

University of Iowa

lowa City, Iowd 52242

(319) $353-4276$

(There are a number of programs that are each related to particular institutions in Michigan and all of them have excellent resources, so here are several listed.) 
Michigan State University

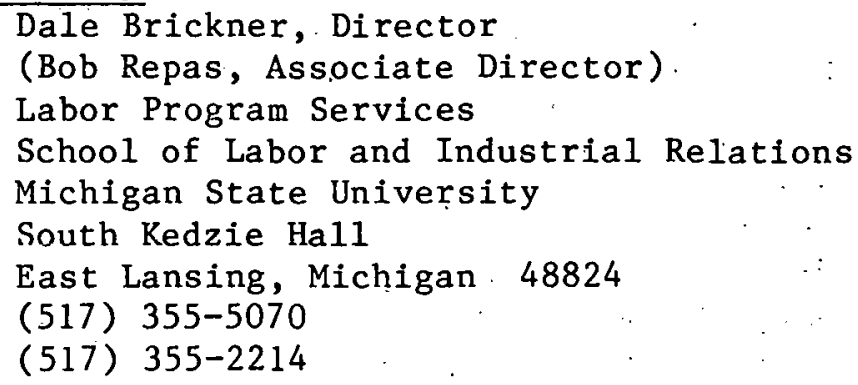

Northern Michigan University

Joaquin Gomez, Labor Consultant

Labor Education Programs

Bureau of Management Training and Economic Development

Division of Continuing Education

Northern Michigan University

Marquette, Michigan 49855

(906) 227-2101

Oakland University

Don Stevens, Director

(Former President Michigan AFL-CIO)

Labor Education Service

Division of Continuing Education

304 Wilson Ha11

Oakland University

Rochester, Michigan 48063

(313) $377-3124$

University of Michigan

(Ann Arbor and Wayne State Campuses, respectively)

Hy Kornbluhm, Codirector

Labor Studies Center

Institute of Labor and Industrial Relations

109 Museums Annex

University of Michigan

Ann Arbor, Michigan 48109

(313) 764-0492

Eugene Brook, Codirector

Labor Studies Center

Institute of Labor and Industrlal Relations

Wayne State University

5475 Woodward Avenue

Detroit, Michigan 48202

(315) 577-2191 
Ohio State University

Charles J. Slanicka, Director

Labor Education and Research Services

Ohio State University

1810 College Road

Columbus, Ohio 43210

(614) 422-8157

(There are three satellite offices and program centers in Ohio on other state institutional campuses or branches of Ohio State University--but Slanicka is key to the contacts.)

University of Wisconsin

Robert' Ozanne, Director

School for Workers

UnIvessity of Wicconsin

825 Extension Building

432 N. Lake

Madison, Wisconsin 53706

(608) 262-2111

University of Wisconsin at Milwaukee

(This is really a satellite of the School for Workers Program at Madison.)

Irving Brotslaw, Associate Director

Schon1. for Workers

University of Wisconsin at Milwaukee

929 N. Sixth Street

Milwaukee, Wisconsin 53203

(414) $224-4175$

One other name should be added to this total list, inasmuch as there is now a coordinated listing of all of the apprenticeshlp training directors in the United States. Supposedly the list is updated from.time to time. The list is maintained by:

Fred Hoehler, Director

George Meany AFL-Liu Labus 3tudieo Contor

10000 New Hampshire Avenue

Silver Springs, Maryland 20903

(jo1) $431=6400$ 
(Especially prepared for the Mid-American Solar Energy Complex)

United Association (Plumbers and Fitters)

Allyn Paramenter, Director of Training

United Association of Journeymen and Apprentices of the

Plumbing and Pipe Fitting Industry

901 Massachusetts Avenue, N.W.

Washington, D.C. 20001

(202) 628-5823

Sheet Metal Workers International Association

Lawrence J. Cassidy, Assistant to the General President Sheet Metal Workers International Association

1750 New York Avénue, N.W

Washington, D.C. 20006

(202) 296-5880

A1 Thiel, Training Director

Sheet Metal Workers' Local 80 Training Center

32700 Dequindre

Warren, Minnesota 48092

(313) $979-5190$

IBEW (Electrical Workers)

J. M. Parker, Director, Construction and Maintenance Department

International Brotherhood of Electrical Workers

1125 Fiftcenth 3Lreer, N.W.

Washington, D.C. 20005

(202) 833-7066

Carpenters and Ininers

James Tinkcom, Training Director

United Brotherhoud of Carpenters and Joiners of Anerica Carpenter's Building

101 Constitution Avenue, N.W.

Washington, D.C. 20001

(202) 546-6206 


\section{AFL-CIO BUILDING AND CONSTRUCTION TRADES DEPARTMENTS}

Robert A. Georgine, President

AFL-CIO Building and Construction

Trades Department

603 AFL-CIO Headquarters

815 Sixteenth Street, N.W.

Washington, D.C. 20006
Lynn Arnaiz, Secretary to the President

\section{BOILERMAKERS}

Harold J. Buoy, President International Brotherhood of

Boilermakers

New Brotherhood Building

8 th Street at State-Avenue

Kansas City, Kansas 66101
- Henry Gertz, Assistant Director, Construction Division
- Inturnational Brotherhood of Boilermakers
700 Railway Labor Building
400 lst Street, N.W. Washington, D.C. 20001

\section{BRICKLAYERS}

Thomas F. Murphy, President International Union of Bricklayers Merlin Taylor, Assistant to the and Allied Craftsmen

815 Fifteenth Street, N.W. Washington, D.C. 20005

\section{CARPENTERS}

W111lam sidell, Prositent. United Brotherhood of Carpenters and Joiners of America Carpenter's Bullding 101 Constitution Avenue, N.W. Washington, D.C. 20001
Patrick Campbe11, Vice-President Richard Cox, Assistanl Li the President

E. Jimmy Jones, Assistant to the Preslient

Lynn Kinter, Contractor

\section{CEMENT MASONS}

Joseph T. Power, President Operative Plasterers and Cement,

Masons International Association of the United States and Canada 1125 Seventeenth Street, N.W. Washington, D.C. 20036
James J. Boyle, Vice-President

Melvin H. Roots, Executive VicePresident

Robert J. Holton, General Secretary-Treasurer

John E. Hauk, International

Representative 


\section{FINISHERS}

Pascal Di James, President

Tile, Marble, Terrazzo, Finishers and Shopmen International Union 801 N. Pitt Street, Suite 116

Alexandria, Virginia 22314

FLINT GLASS WORKERS

George M. Parker, President American Flint Glass Workers

1440 S. Byrne Road

Toledo, Ohio 43614

\section{ELECTRICAL, RADIO, AND MACHINE}

David J. Fitzmaurice, President

International Union of Electrical, Radio, and Machine Workers

1126 16th Street, N.W.

Washington, D.C. 20036

\section{ELEVATOR CONSTRUCTORS}

Everett A. Treadway, President

International Union of Elevator Constructors

Clark Building, Suite 332

5565 Sterrett Place

Columbia, Maryland 21004

\section{ENGINEERS}

J. C. Turner, President

International Union of Operating

Engineers

1125 Seventeenth Street, N.W.

Washington, D.C. 20036
Michael. Con1ins, Assistant Director of Education and Training

Al Lake, Assistant to the General President Richard Bailey, Director of Jurisdiction

\section{GRANITE CUTTERS}

Joseph P. Ricciarelli, International President The Granite Cutters International Association of America P.0. Box 368

Quincy, Massachusetts 02169 
Charles H. Pillard, President International Brotherhood of

Electrical Workers

1125 Fifteenth Street, N.W. Wașhington, D.C. 20005
Marcus Loftus, Administrative Assistant to the President William McBride, Assistant to the President

Vincent 0'Reilly, Director Utility Deparcment

J. M. Parker, Director, Construction and Maintenance Department

\section{INSULATORS}

Andrew T. Haas, President

International Association of Heat and Frost Insulators and Asbestos Workers

505 Machinists Building

1300 Connecticut Avenue, N.W.

Washington, D.C. 20036
Joseph P. Zinser, Jurisidictlonal Director

\section{IRON WORKERS}

John H. Lyons, President

International Association of bridge and Structural Iron Workers

1750 Ncw York Avenue, N.W.

Washington, D.C. ZUUÜ
Robert McVay, Direclus uf

Jurlsdilliuns

\section{LADORERS}

Angelo Fosco, President taborers International Union of North America 905 Sixteenth Street, N.W. Washington, D.C. 20006
Marrlun Parsuns, Training Director James R. Sheets, Research Director

\section{LATHERS}

Charles L. Brodeur, General President

International Union of Wood, Wire, and Metal Lathers

815 Sixteenth Street, N.W.

Washington, D.C. 20006 


\section{MACHINISTS}

William W. Winpisinger, President

I. ternational Association of Machinists and Aerospace Workers.

Machinists Building

1300 Connecticut Avenue, N.W.

Washington, D.C. 20036
Barbara Shailor, Legislative Representative

\section{PAINTERS}

S. Frank Raftery, President International Brotherhood of Palnters and Allied Trades of the United States and Canada United Unions Building 1750 New York Avenue, N.W. Washington, D.C. 20006
William A. Duva1, Genera1 VicePresident

Robert C. Welch, Special Assistant to the General President

James Shay, Director of Jurisdictions

\section{PLUMBERS AND FITTERS (UA)}

Martin J. Ward, General

President

United Association of Journeymen and Apprentices of the Plumbing and Pipe Fitting Industry of the United States and Canada

901 Massachusetts Avenue, N.W.

Washington, D.C. 20001
Allyn Paramenter, Director of Training

Dominic Carnevale, Administrative Assistant to the General President

ROOFERS

Roy E. Johnson, President

United Slate, Tile, and Composition

Roofers, Damp and Waterproof

Workers Association

1125 Seventeenth Street, N.W.

Washington, D.C. 20036
Vince Garito, International

Representative

\section{SHEET METAL}

Edward J. Carlough, President Sheet Metal Workers International

Association

United Unions Building

1750 New York Avenue, N.W.

Washington, D.C. 20036
Larry Cassidy, Assistant to the

General President

Walter J. Cosel, Solar Consultant

Nick Lamb, Assistant

Maria Striefsky, Secretary to the

General Preoident 
Dave Harrington, Training

Director

National Training Fund

Sheet Metal and Air Conditioning Industry

1900 L. Street, \#405

Washington, D.C. 20036
W. L. Filippini, Administrator National Training Fund

Sheet Metal and Air Conditioning Industry

1900 L. Stree, \#405

Washingtnn, D.C. 20036

\section{TEAMSTERS}

Frank E. Fitzsimmons, Genera1

Dave Sweeney, Director President

International Brotherhood of

Office of Public Relations and Yublicactons

Teamsters

25 Louisiana Avenue, N.W.

Washington, D.C. 20001

UAW (AUTO WORKERS)

Douglas A. Fraser, President

United Auto Workers

John Yolton, Administrative

8000 E. Jefferson Avenue

Assistant, Department of Conservation

Detroit, Mich1gan 48214

\section{UNITED GLASS AND CERAMIC WORKERS}

Joseph Roman, President

United Glass and Ceramic Workers of North America

556 East Town Street

Columbus, Ohio 43215

UNITED STEEL WORKERS

Lloyd McBride, President

United Steel Workers of America

Five Gateway Center

Pit.tsburgh, Pennsylvania 15222

\section{INTERNATIONAL LABOR PRESS ASSOCIATION}

Allen Zack, Secretary-Treasurer International Labor Press

Association

$\triangle F L-C I O$ Building

815 Sixteenth Street, N.W.

Washington, D.C.
Judy Robbins, Administrative Assistant 
No. of Copies

1

1

2

1

2

1

1

1

1
Distribution

Department of Energy:

Attn: DOE, SERI Site office

Contracting officer

Charles M. Skinner

Chicago Operations office

Interim Program Division

Attn: M. E. Jackson

Division of Solar Technology

Office of Asst. Director for Administration

Attn: R. H. Annan

Office of Asst. Secretary for

Conservation \& Solar Applications

Attn: R. Scott

Office of Solar, Geothermal,

Electric \& Storage Programs

Attn: H. H. Marvin

Division of Energy Technology

Administration

Attn: S. Hansen

Division of D1stributed Solar

Technology

Office of the Director

Attn: R. San Martin

Division of Central Solar

Technology

Office of the Director

Attn: $H$. Coleman

Division of Energy Storage Systems

office of the Director

Attn: G. Pezdirtz

Division of Planning \& Energy Transfer

Office of the Director

Attn: M. Adams 